Prepared in cooperation with the U.S. Army Corps of Engineers,

South Florida Water Management District, and

Florida Department of Agriculture and Consumer Services

\title{
Concentrations and Loads of Nutrients in the Tributaries of the Lake Okeechobee Watershed, South-Central Florida, Water Years 2004-2008
}

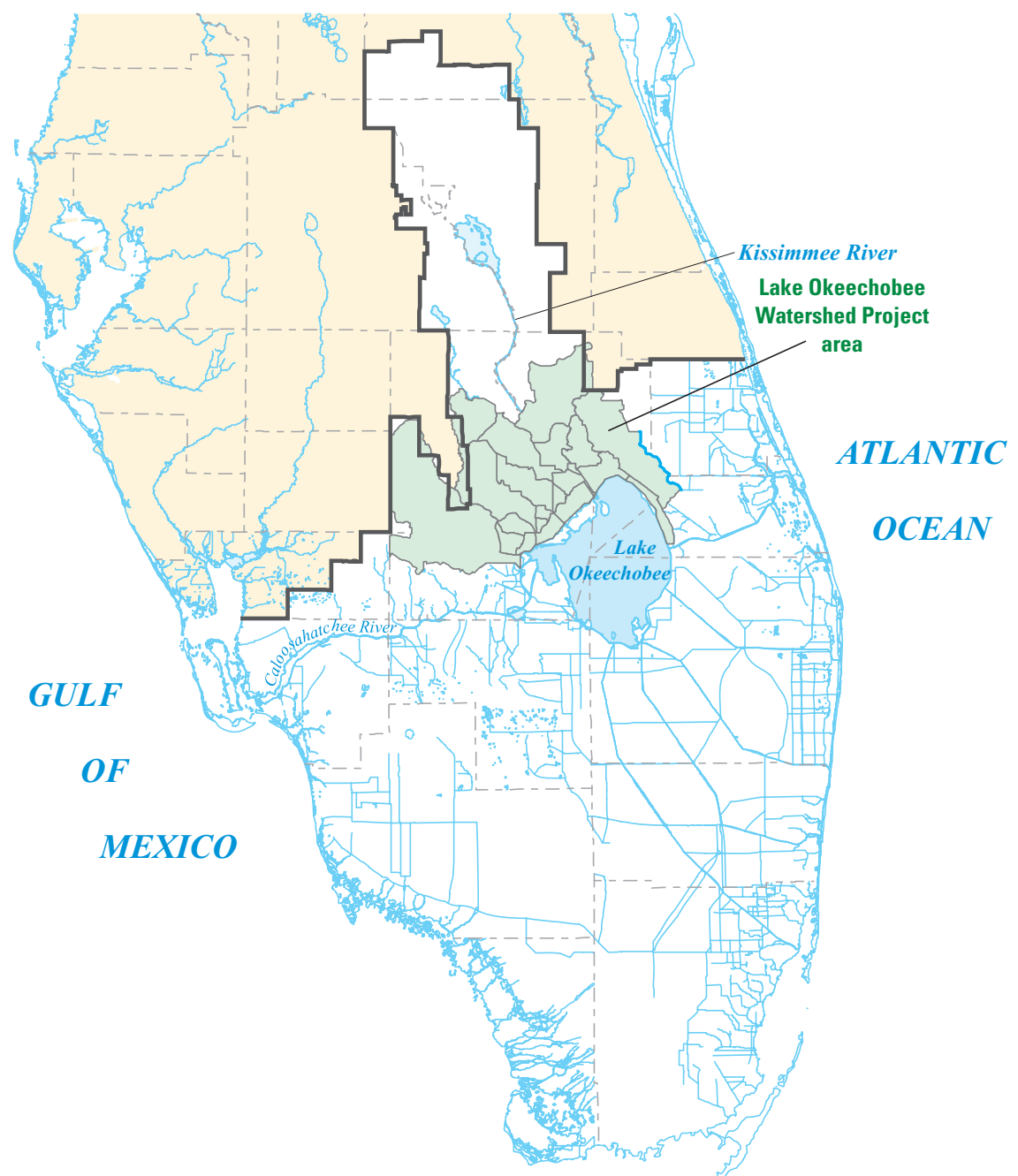

Data Series 613 



\section{Concentrations and Loads of Nutrients in the Tributaries of the Lake Okeechobee Watershed, South-Central Florida, Water Years 2004-2008}

By Michael J. Byrne, Sr., and Molly S. Wood

Prepared in cooperation with the

U.S. Army Corps of Engineers,

South Florida Water Management District, and

Florida Department of Agriculture and Consumer Services

Data Series 613 


\title{
U.S. Department of the Interior \\ KEN SALAZAR, Secretary \\ U.S. Geological Survey \\ Marcia K. McNutt, Director
}

\author{
U.S. Geological Survey, Reston, Virginia: 2012
}

For more information on the USGS - the Federal source for science about the Earth, its natural and living resources, natural hazards, and the environment, visit http://www.usgs.gov or call 1-888-ASK-USGS.

For an overview of USGS information products, including maps, imagery, and publications, visit http://www.usgs.gov/pubprod

To order this and other USGS information products, visit http://store.usgs.gov

Any use of trade, product, or firm names is for descriptive purposes only and does not imply endorsement by the U.S. Government.

Although this report is in the public domain, permission must be secured from the individual copyright owners to reproduce any copyrighted materials contained within this report.

Suggested citation:

Byrne, M.J., Sr., and Wood, M.S., 2012, Concentrations and Loads of Nutrients in the Tributaries of the Lake Okeechobee Watershed, South-Central Florida, Water Years 2004-2008: U.S. Geological Survey

Data Series 613, 22 p. (available online at http://pubs.usgs.gov/ds/613). 


\section{Contents}

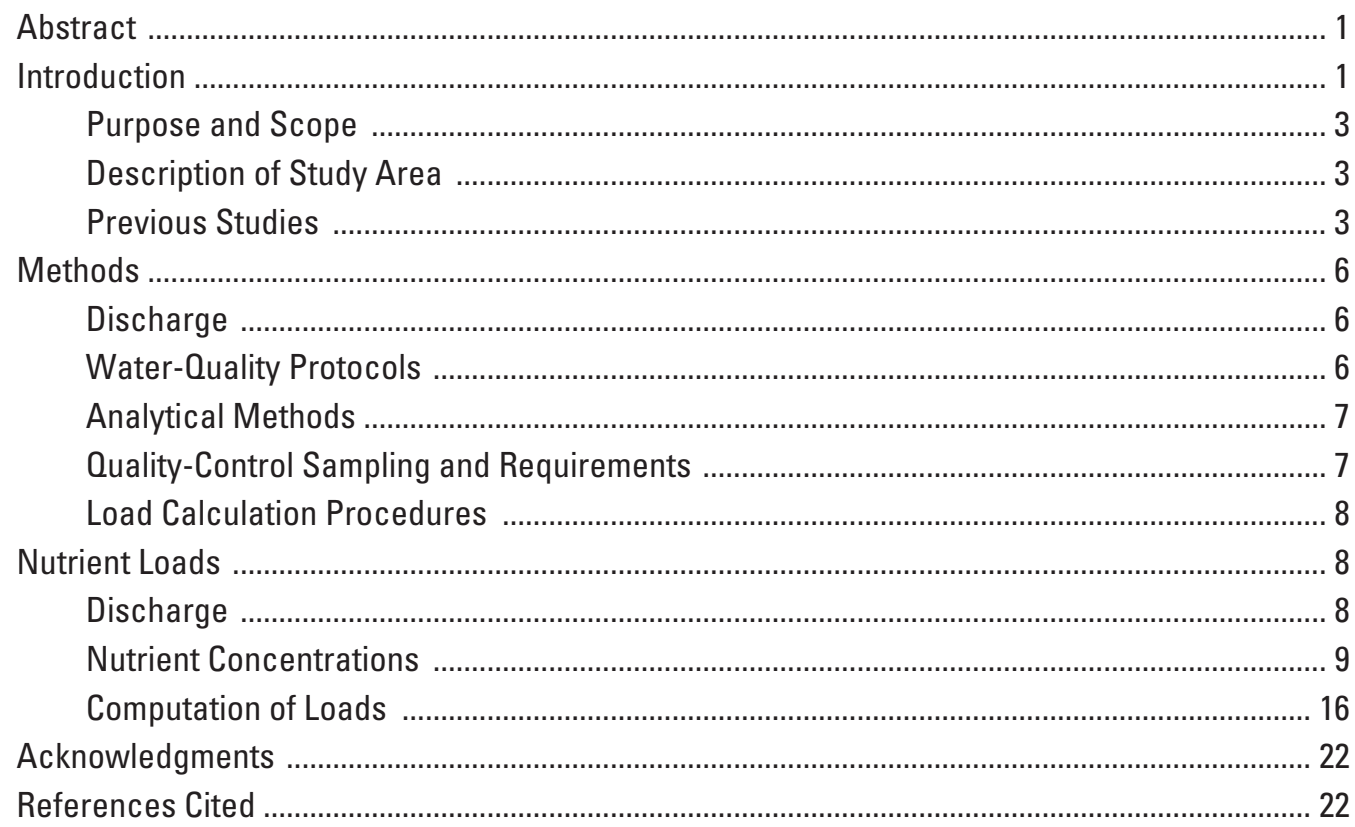

\section{Figures}

1. Map showing location of the Lake Okeechobee Watershed Project area in Florida ..... 2

2. Map showing location of regional subwatershed, basins, and monitoring sites in the Lake Okeechobee Watershed Project area ................................................................ 4

3. Graph showing monthly rainfall measured at Peace River at Fort Meade and at Taylor Creek near Cypress Quarters .............................................................................. 8

4. Graphs showing monthly discharge at sites east of the Kissimmee River,

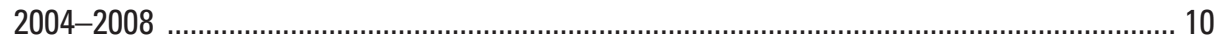

5. Graphs showing monthly discharge at sites west of the

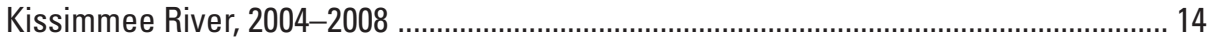

6. Box plot of total phosphorus concentrations by site, 2004-2008 ................................. 17

7. Box plot of total organic nitrogen plus ammonia concentration by site,

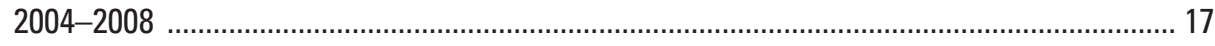

8. Box plot of total nitrite plus nitrate concentrations by site, 2004-2008 ......................... 19 


\section{Tables}

1. Description of monitoring sites in the Lake Okeechobee Watershed Project area ........ 5

2. Calibration acceptance criteria for field measurements ................................................ 7

3. Analytical methods prescribed for water-quality constituents ...................................... 7

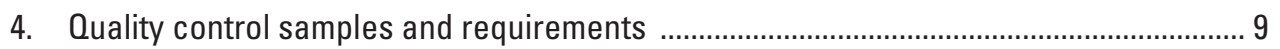

5. Summary of annual discharge in the Lake Okeechobee watershed, 2004-2008 ........... 16

6. Statistical analysis of nutrient concentrations in the Lake Okeechobee watershed, 2004-2008

7. Summary of annual nutrient loads in the Lake Okeechobee watershed, 2004-2008

\section{Conversion Factors, Abbreviations, and Datums}

Inch/Pound to SI Units

\begin{tabular}{lcl}
\hline \multicolumn{1}{c}{ Multiply } & \multicolumn{1}{c}{ By } & \multicolumn{1}{c}{ To obtain } \\
\hline inch (in.) & 2.54 & centimeter \\
inch per year (in/yr) & 2.54 & centimeter per year \\
foot (ft) & 0.3048 & meter \\
mile (mi) & 1.609 & kilometer \\
square mile $\left(\mathrm{mi}^{2}\right)$ & 2.590 & square kilometer $\left(\mathrm{km}^{2}\right)$ \\
acre & 4,047 & square meter \\
acre-foot $($ acre-ft) & 1,233 & cubic meter \\
cubic foot per second $\left(\mathrm{ft}^{3} / \mathrm{s}\right)$ & 0.02832 & cubic meter per second \\
\hline
\end{tabular}

Vertical coordination information is referenced to the National Geodetic Vertical Datum of 1929 (NGVD 29) and the North American Vertical Datum of 1988 (NAVD 88).

Horizontal coordinate information is referenced to the North American Datum of 1927 (NAD 27).

Elevation, as used in this report, refers to distance above the vertical datum. 


\section{Acronyms}

$\begin{array}{ll}\text { ACS } & \text { American Chemical Society } \\ \text { ADCP } & \text { acoustic Doppler current profiler } \\ \text { ADVM } & \text { acoustic Doppler velocity meter } \\ \text { CERP } & \text { Comprehensive Everglades Restoration Plan } \\ \text { L } & \text { liter } \\ \text { LOWP } & \text { Lake Okeechobee Watershed Project } \\ \text { MT } & \text { metric ton } \\ \mu \mathrm{g} / \mathrm{L} & \text { microgram per liter } \\ \text { mg/L } & \text { milligram per liter } \\ \mathrm{mL} & \text { milliliter } \\ \text { NO } & + \text { NO } \\ 3 & \text { Total nitrite plus nitrate } \\ \text { SFWMD } & \text { South Florida Water Management District } \\ \text { TKN } & \text { Total organic nitrogen plus ammonia } \\ \text { TP } & \text { Total phosphorus } \\ \text { USACE } & \text { U.S. Army Corps of Engineers } \\ \text { USEPA } & \text { U.S. Environmental Protection Agency } \\ \text { USGS } & \text { U.S. Geological Survey } \\ \text { WY } & \text { water year }\end{array}$





\title{
Concentrations and Loads of Nutrients in the Tributaries of the Lake Okeechobee Watershed, South-Central Florida, Water Years 2004-2008
}

\author{
By Michael J. Byrne, Sr., and Molly S. Wood
}

\section{Abstract}

Lake Okeechobee in south-central Florida is the second largest freshwater lake in the contiguous United States. Excessive phosphorus loading, harmful high and low water levels, and rapid expansion of non-native vegetation have threatened the health of the lake in recent decades. A study was conducted to monitor discharge and nutrient concentrations from selected tributaries into Lake Okeechobee and to evaluate nutrient loads. The data analysis was performed at 16 monitoring stations from December 2003 to September 2008.

Annual and seasonal discharge measured at monitoring stations is affected by rainfall. Hurricanes affected three wet years $(2004,2005$, and the latter part of 2008) and resulted in substantially greater discharge than the drought years of 2006, 2007, and the early part of 2008. Rainfall supplies about 50 percent of the water to Lake Okeechobee, discharge from the Kissimmee River supplies about 25 percent, and discharge from tributaries and groundwater seepage along the lake perimeter collectively provide the remaining 25 percent. Annually, tributary discharge from basins located on the west side of the Kissimmee River is about 5 to 6 times greater than that from basins located on the east side. For the purposes of this study, the basins on the east side of the Kissimmee River are called "priority basins" because of elevated phosphorus concentrations, while those on the west side are called "nonpriority" basins. Total annual discharge in the non-priority basins ranged from 245,000 acre-feet (acre-ft) in 2007 to $1,322,000$ acre-ft in 2005, while annual discharge from the priority basins ranged from 41,000 acre-ft in 2007 to 219,000 acre-ft in 2005.

Mean total phosphorus concentrations ranged from 0.10 to 0.54 milligrams per liter $(\mathrm{mg} / \mathrm{L})$ at the 16 tributaries during 2004-2008. Mean concentrations were significantly higher at priority basin sites than at non-priority basin sites, particularly at Arbuckle Creek and C 41A Canal. Concentrations of organic nitrogen plus ammonia ranged from 1.27 to 2.96 $\mathrm{mg} / \mathrm{L}$ at the 16 tributaries during 2004-2008. Mean concentrations were highest at Fisheating Creek at Lake Placid (a non-priority site), and lowest at Wolff Creek, Taylor Creek near Grassy Island, and Otter Creek (three priority basin sites), and at Arbuckle Creek (a non-priority basin site). Mean concentrations of nitrite plus nitrate ranged from 0.01 to 0.55 $\mathrm{mg} / \mathrm{L}$ at the 16 tributaries during 2004-2008. Mean concentrations measured in priority basins were significantly higher than those measured in non-priority basins.

Nutrient concentrations were substantially lower in the non-priority basins; however, total loads were substantially higher due to discharge that was 5 to 6 times greater than from the priority basins. Total phosphorus, organic nitrogen plus ammonia, and nitrite plus nitrate loads from the non-priority basins were $1.5,4.5$, and 3.5 times greater, respectively, than were loads from the priority basins.

In the non-priority basins, total phosphorus loads ranged from 35 metric tons (MT) in 2007 to 247 MT in 2005. In the priority basins, the loads ranged from 18 MT in 2007 to $136 \mathrm{MT}$ in 2005. In the non-priority basins, organic nitrogen plus ammonia loads ranged from $337 \mathrm{MT}$ in 2007 to 2,817 MT in 2005. In the priority basins, organic nitrogen plus ammonia loads ranged from 85 MT in 2007 to 503 MT in 2005. In the non-priority basins, nitrite plus nitrate loads ranged from 34 MT in 2007 to 143 MT in 2005. In the priority basins, nitrite plus nitrate loads ranged from 4 MT in 2007 to 27 MT in 2005 .

\section{Introduction}

Lake Okeechobee, located in south-central Florida, is the second largest freshwater lake in the contiguous United States, with a surface area of 430,000 acres (670 square miles; $\mathrm{mi}^{2}$ ). The lake and its watershed are key components of Florida's Kissimmee-Okeechobee-Everglades ecosystem, extending from the Kissimmee River in the north to Florida Bay in the south (fig. 1). Lake Okeechobee is a natural habitat for fish, wading birds, and other wildlife, supplies essential water for urban and agricultural purposes, provides flood protection, and is home to a multimillion dollar sport and commercial fishery. Excessive phosphorus loading, harmful high and low water levels, and rapid expansion of exotic vegetation have threatened the health of the lake in recent decades (Havens and others, 2003). In 2000, the Florida Legislature enacted the Lake Okeechobee Protection Program (State of Florida, 2000) to reduce phosphorus loads to the lake and to support watershed restoration. 


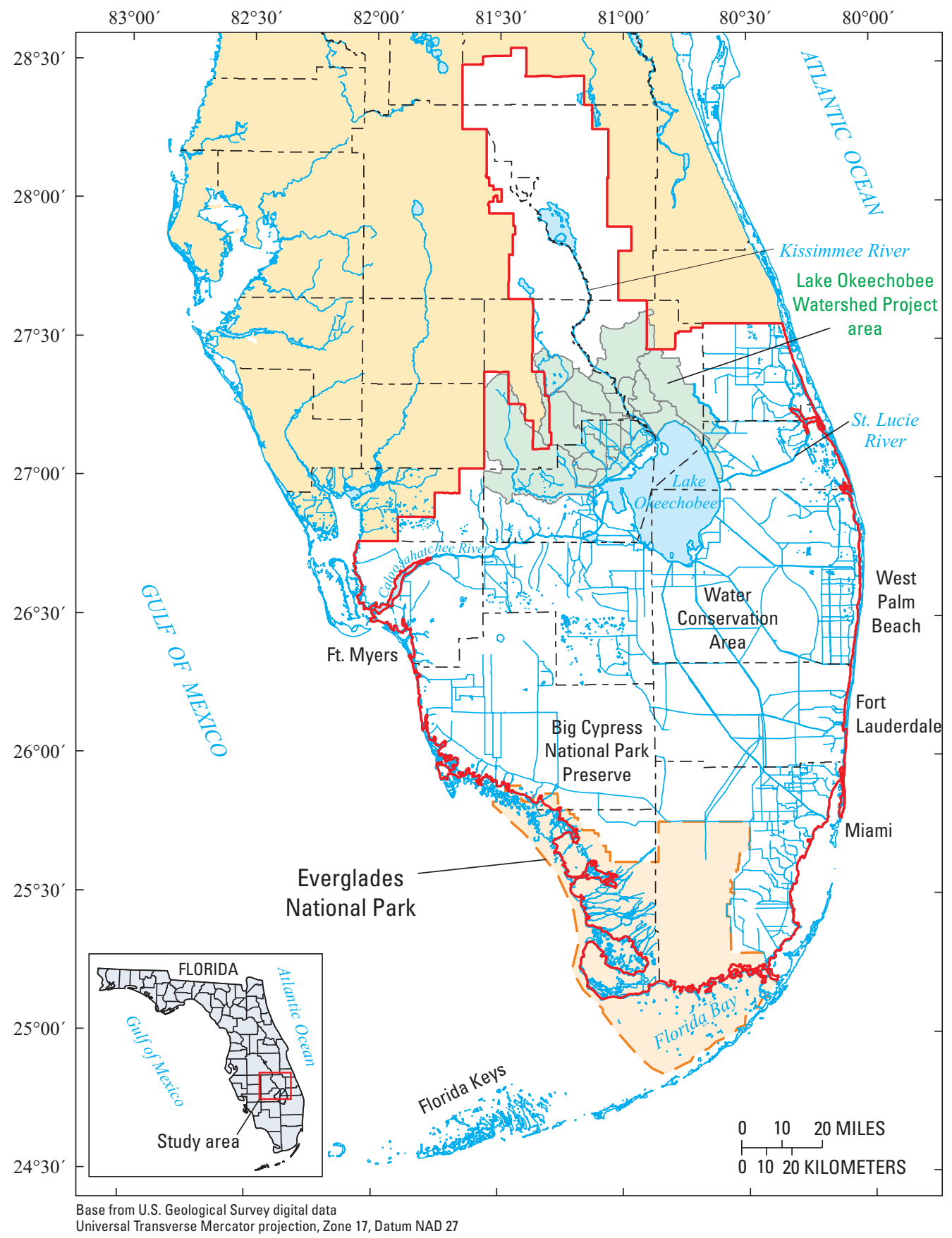

Figure 1. Location of the Lake Okeechobee Watershed Project area in Florida. 
The Kissimmee-Okeechobee-Everglades ecosystem is negatively impacted when phosphorus concentrations exceed 40 micrograms per liter ( $\mu \mathrm{g} / \mathrm{L}$; Zhang and others, 2009). Concentrations and loads of nutrients for Lake Okeechobee are reported as rolling 5-year averages to compensate for climate variability. The current nearshore phosphorus concentration (2004-2008) is $114 \mu \mathrm{g} / \mathrm{L}$ and the phosphorus load is 551 MT per year (Zhang and others, 2009). The goal of the Lake Okeechobee Protection Plan is to reduce the annual phosphorus loads to 140 MT by 2015 (State of Florida, 2000).

\section{Purpose and Scope}

The U.S. Geological Survey (USGS), in cooperation with the U.S. Army Corps of Engineers (USACE), South Florida Water Management District (SFWMD), and Florida Department of Agriculture and Consumer Services, began a 10-year study in 2004 to monitor nutrient loads from 16 tributaries to Lake Okeechobee. The objectives of the study are to: (1) measure discharge from tributaries flowing into Lake Okeechobee; (2) measure key water-quality constituents (phosphorus and nitrogen); (3) calculate nutrient load from the tributaries to Lake Okeechobee; and (4) describe changes on a subbasin scale. To achieve these goals, 16 hydrologic and water-quality monitoring stations (fig. 2 ; table 1 ) were established in tributaries north and west of Lake Okeechobee for the purpose of analyzing continuous discharge and stage, total phosphorus (TP), total organic nitrogen plus ammonia (TKN), total nitrite plus nitrate $\left(\mathrm{NO}_{2}+\mathrm{NO}_{3}\right)$, dissolved phosphorus, dissolved orthophosphate, dissolved ammonia, and total suspended solids. The data from this study will be used to assess watershed restoration efforts.

The purpose of this report is to describe nutrient loads discharged from selected tributaries into Lake Okeechobee. The data analysis was performed at 16 streamflow, stage, and water-quality monitoring stations from December 2003 to September 2008. The data are summarized for all stations and include monthly mean discharge, nutrient concentrations, and nutrient loads (phosphorus and nitrogen). The data cited in this report were accessed on January 5, 2011, at http://sofia.usgs.gov/exchange/lowp/.

\section{Description of Study Area}

The Lake Okeechobee watershed encompasses 5,400 $\mathrm{mi}^{2}$ in south-central Florida (fig. 1) and is dominated by agriculture with improved pastures for cattle grazing, orange groves, and dairy farms. Agricultural runoff from the watershed area has high concentrations of both phosphorus and nitrogen.

The climate in central Florida is classified as humid subtropical, with a warm wet season from June to November and a mild dry season from December through May. The average rainfall is 52 inches per year (in/yr), and mostly occurs from June through September. Interannual variation is common with hurricanes and droughts. Lake Okeechobee receives
50 percent of its freshwater from rainfall, 25 percent from the Kissimmee River, and 25 percent from contributing tributaries and groundwater seepage along the lake perimeter (M. Wood, and others, USGS, written commun., June 2003).

The Kissimmee River is the main tributary to Lake Okeechobee; it was dredged to a depth of $30 \mathrm{ft}$ and channelized in the 1960s. This channelization increased the delivery of nutrients and suspended sediment to Lake Okeechobee and led to the loss of wetlands in the floodplain. The current Kissimmee River restoration effort is designed to put the curves back into the river in order to reestablish the wetlands and reduce sediment loading.

The Lake Okeechobee Watershed Project area is encompassed by 5 subwatersheds and 20 basins. The subwatersheds are Fisheating Creek, Lake Istokpoga, Indian Prairie, Taylor Creek/Nubbin Slough, and the Lower Kissimmee (fig. 2). Phosphorus load rates have varied over time in the basins as a result of a combination of climatic conditions, land-use changes, and changes in water-management conditions (James and Zhang, 2008). The highest phosphorus concentrations have been identified in four basins (S-191, S-154, S-65D, and S-65E; fig. 2), known as the priority basins, on the east side of the Kissimmee River. Most of the USGS monitoring sites used in the present study are located within the priority basins. The subwatersheds, basins, and monitoring sites in the Lake Okeechobee Watershed Project area are shown on figure 2 and listed in table 1.

Land use consists of wetlands and pasture in the Fisheating Basin and consists of sod, dairies, and the Avon Park Bombing Range in the Lake Istokpoga subwatershed. Land use consists of citrus, sod, and pasture in the C-41 basin and consists of crops and pasture in the C-41A basin (Indian Prairie subwatershed). Land use in priority basin S-191 (Taylor Creek/Nubbin Slough subwatershed) consists of pasture, citrus, dairies, and wetlands. Land use in priority basin S-65D (Lower Kissimmee subwatershed) and priority basin S-154 (Taylor Creek/Nubbin Slough subwatershed) consists of wetlands, dairies, and pasture (Zhang and others, 2009).

\section{Previous Studies}

Previous research on nutrient loads to Lake Okeechobee was published between 1971 and 2008. Flaig and Reddy (1995) summarized the findings from a workshop held in 1993, which was designed to study the fate and transport of phosphorous in the Lake Okeechobee watershed. Their key findings revealed that phosphorus retention is dependent upon soil composition, moisture content, phosphorous loads, and $\mathrm{pH}$. In addition, Flaig and Reddy determined that best management practices can lose their effectiveness over time due to reaching the effective nutrient capacity in the wetland or lake. In another study on soil phosphorous storage around Lake Okeechobee (McKee and others, 2008), researchers determined that the ability of wetlands to retain and immobilize phosphorous better than surrounding uplands was statistically significant. 


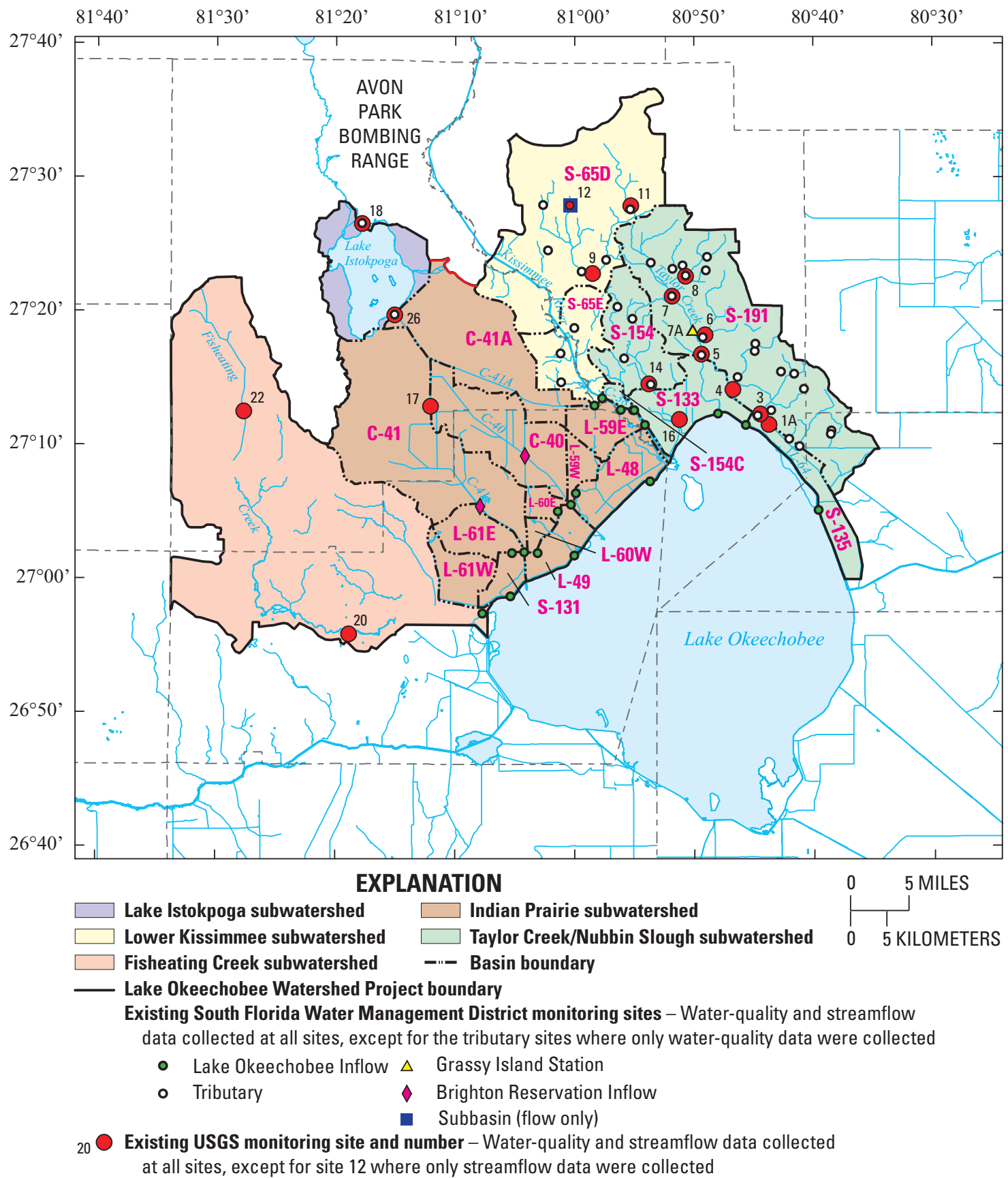

Figure 2. Location of regional subwatershed, basins, and monitoring sites in the Lake Okeechobee Watershed Project area in Florida. 
Table 1. Description of monitoring sites in the Lake Okeechobee watershed project area.

[no., number; site 1A has replaced original sites 1 and 2; site 7A was established downstream of the Taylor Creek remediation project in August 2004; water-quality and streamflow data were collected at all sites; USGS, U.S. Geological Survey, Florida]

\begin{tabular}{|c|c|c|c|c|c|c|}
\hline $\begin{array}{l}\text { Site } \\
\text { no. }\end{array}$ & Latitude & Longitude & $\begin{array}{l}\text { Site name } \\
\text { (figure 2) }\end{array}$ & $\begin{array}{l}\text { USGS site } \\
\text { identifier }\end{array}$ & $\begin{array}{c}\text { Subwatershed } \\
\text { (from James and Zhang, 2008) }\end{array}$ & Basin \\
\hline $1 \mathrm{~A}$ & $27^{\circ} 11^{\prime} 35^{\prime \prime}$ & $80^{\circ} 43^{\prime} 49^{\prime \prime}$ & $\begin{array}{l}\text { L-63 Interceptor at CR15A near } \\
\text { Okeechobee, Fla. }\end{array}$ & 02275631 & Taylor Creek/Nubbin Slough & S-191 \\
\hline 3 & $27^{\circ} 12^{\prime} 25^{\prime \prime}$ & $80^{\circ} 44^{\prime} 30^{\prime \prime}$ & $\begin{array}{l}\text { Nubbin Slough upstream from L-63 } \\
\text { Interceptor near Okeechobee, Fla. }\end{array}$ & 02275625 & Taylor Creek/Nubbin Slough & S-191 \\
\hline 4 & $27^{\circ} 14^{\prime} 12^{\prime \prime}$ & $80^{\circ} 46^{\prime} 50^{\prime \prime}$ & $\begin{array}{l}\text { Mosquito Creek at Highway } 710 \\
\text { near Okeechobee, Fla. }\end{array}$ & 02275197 & Taylor Creek/Nubbin Slough & S-191 \\
\hline 5 & $27^{\circ} 16^{\prime} 49^{\prime \prime}$ & $80^{\circ} 49^{\prime} 27^{\prime \prime}$ & $\begin{array}{l}\text { Wolff Creek downstream from } \\
\text { Cemetery Road near Okeechobee, } \\
\text { Fla. }\end{array}$ & 02274505 & Taylor Creek/Nubbin Slough & S-191 \\
\hline 6 & $27^{\circ} 18^{\prime} 16^{\prime \prime}$ & $80^{\circ} 49^{\prime} 09^{\prime \prime}$ & $\begin{array}{l}\text { Williamson Ditch behind Eckerd } \\
\text { Youth Center near Okeechobee, } \\
\text { Fla. }\end{array}$ & 02274490 & Taylor Creek/Nubbin Slough & S-191 \\
\hline 8 & $27^{\circ} 22^{\prime} 39^{\prime \prime}$ & $80^{\circ} 50^{\prime} 42^{\prime \prime}$ & $\begin{array}{l}\text { Otter Creek at Old Highway } 68 \text { near } \\
\text { Okeechobee, Fla. }\end{array}$ & 02274005 & Taylor Creek/Nubbin Slough & S-191 \\
\hline 9 & $27^{\circ} 22^{\prime} 50^{\prime \prime}$ & $80^{\circ} 58^{\prime} 34^{\prime \prime}$ & $\begin{array}{l}\text { Cypress Slough at Lamb Island } \\
\text { Road near Basinger, Fla. }\end{array}$ & 02272676 & Lower Kissimmee Basins & S-65D \\
\hline 11 & $27^{\circ} 27^{\prime} 54^{\prime \prime}$ & $80^{\circ} 55^{\prime} 22^{\prime \prime}$ & $\begin{array}{l}\text { Fish Slough at CR724 near } \\
\text { Basinger, Fla. }\end{array}$ & 02272650 & Lower Kissimmee Basins & S-65D \\
\hline 14 & $27^{\circ} 14^{\prime} 37^{\prime \prime}$ & $80^{\circ} 53^{\prime} 51^{\prime \prime}$ & $\begin{array}{l}\text { Popash Slough at Highway } 70 \text { near } \\
\text { Okeechobee, Fla. }\end{array}$ & 02273630 & Taylor Creek/Nubbin Slough & S-154 \\
\hline 17 & $27^{\circ} 12^{\prime} 35^{\prime \prime}$ & $81^{\circ} 12^{\prime} 05^{\prime \prime}$ & $\begin{array}{l}\text { Canal C-41 at Highway } 70 \text { near } \\
\text { Brighton, Fla. }\end{array}$ & 02273230 & Indian Prairie Basins & C-41 \\
\hline 26 & $27^{\circ} 19^{\prime} 55^{\prime \prime}$ & $81^{\circ} 15^{\prime} 05^{\prime \prime}$ & $\begin{array}{l}\text { Canal C-41A at S- } 68 \text { on CR621 near } \\
\text { Lake Placid, Fla. }\end{array}$ & 02273198 & Indian Prairie Basins & $\mathrm{C}-41 \mathrm{~A}$ \\
\hline
\end{tabular}


Havens and others (2003) describe Lake Okeechobee as being hypereutrophic due to excess phosphorus concentration. Generally, hypereutrophic conditions can be related to the predominance of algae species. From the 1970s to the 1990s, the ratio of total nitrogen and total phosphorus has decreased from 30:1 to 15:1; the distinct boundary between nitrogen limitation to phosphorus limitation is 22:1. Therefore, Lake Okeechobee is nitrogen limited and excess phosphorus is not assimilated.

Miller and McPherson (2008) analyzed 30 years of water-quality data collected south of Lake Okeechobee and north of Everglades National Park. They determined that in order to detect trends in water quality, the data must be comparable and collected over a long period of time to adjust for seasonal and annual fluctuations in rainfall. The USGS statistical software ESTREND used in those analyses requires a minimum of 10 years of water-quality data for trend analysis (Schertz and others, 1991).

\section{Methods}

Streamflow gaging and water-quality sampling methods used for this study conform to Comprehensive Everglades Restoration Plan (CERP) quality assurance (RECOVER, 2003) and USGS protocols. The USGS operates a comprehensive quality assurance/quality control program to ensure quality data collection (U.S. Geological Survey, variously dated).

Monitoring stations were installed in fall 2003 followed by data collection in winter 2003 at all stations except for Taylor Creek at Grassy Island Station (site 7A; fig. 2) where collection began in August 2004. Discharge and stage (water elevation) were collected continuously (15-minute intervals) at all stations. Flow-weighted composite samples were collected weekly or biweekly in an unrefrigerated automatic sampler and analyzed for nutrient concentrations. Manual samples were collected weekly for the first 2 years of the study and sporadically later in the study. These samples were analyzed for TP, TKN, $\mathrm{NO}_{2}+\mathrm{NO}_{3}$, dissolved phosphorus, dissolved orthophosphate, dissolved ammonia, and total suspended solids.

\section{Discharge}

All stations built for this study measured continuous stage and velocity. Data were logged internally at all stations and transmitted by satellite telemetry.

Stage was measured with an incremental shaft encoder inside an 8-in. polyvinyl chloride stilling well. The established National Geodetic Vertical Datum for 1929 (NGVD 29) was used to measure stage for Fisheating Creek at Palmdale (site 20; fig. 2) and the North American Vertical Datum of 1988 (NAVD 88) was used for all the other stations using historic benchmarks and differential levels.

Water velocity was measured continuously at USGS monitoring stations using an acoustic Doppler velocity meter (ADVM). The velocity and stage measurements were then used to compute discharge at sites 1A, 3, 7, 7A, 17, 18, and 26 (fig. 2). Continuous discharge is a product of measured velocity (index velocity) and stage-dependent cross-sectional area. Rated index velocity was determined by comparing mean velocity to index velocity using multiple linear regression techniques. Mean velocity was determined from discharge measurements taken from an acoustic Doppler current profiler (ADCP). The ADCP measurements were taken over a wide range in stage, with periodic measurements taken for verification purposes. The ADCP was also used to define the stagedependant cross-sectional area.

Discharge ratings for the remainder of the sites $(4,5$, $6,8,9,11,14,20$, and 22) were determined empirically by means of periodic measurements of stage and discharge, and the subsequent development of stage-discharge relations. To develop the relations, stage and streamflow are measured over a wide range of stages, then the measured discharge is plotted graphically against concurrent stage to define the rating curve. A stage-discharge relation was used to calculate discharge at the study sites throughout the entire range of stage.

\section{Water-Quality Protocols}

Water-quality data were collected at all discharge monitoring stations. Data collection included composited TP, TKN, and $\mathrm{NO}_{2}+\mathrm{NO}_{3}$ samples, and intermittent waterquality samples for the purpose of calculating nutrient and total suspended sediment loads. The USGS uses nationally consistent techniques to collect water-quality data (U.S. Geological Survey, variously dated). Flow-weighted samples were collected weekly or biweekly, provided that there was sufficient flow passing the site during the week to collect a minimum sample volume in the automatic sampler. The ability to collect enough volume for the TP sample is crucial because phosphorus is the most critical analyte in the monitoring program. During the first 2 years of this study, samples were collected manually only when the automatic sampler had collected the minimum required sample volume and stream water around the site was not stagnant or pooled at the time of the visit. Currently, samples are collected manually during high water events.

Each automatic sampler was triggered to collect a 100 milliliter $(\mathrm{mL})$ aliquot of stream water after a set volume of streamflow had passed the site. Data collected from stagesensing equipment and an ADVM was used to trigger the automatic sampler. The volume of streamflow required to trigger the automatic sampler was set to collect stream water samples as frequently as possible without filling all the automatic sampler bottles before the site was serviced. The trigger volume was small enough to permit resolution during storm events, but large enough to sample diurnal fluctuations in water-quality constituents. The volume of streamflow required to trigger the automatic sampler is different for each site and changed seasonally. 
Flow-weighted composite samples were preserved with sulfuric acid to prevent changes in nitrogen and phosphorus concentrations due to biological activity. Each automatic sampler bottle was preacidified with $1 \mathrm{~mL}$ of 50 percent (by volume) American Chemical Society-grade (ACS-grade), sulfuric acid per $1 \mathrm{~L}$ of sample water. Research by the SFWMD (Burke and others, 2002) indicated that no significant difference in TP, TKN, and $\mathrm{NO}_{2}+\mathrm{NO}_{3}$ was determined from unrefrigerated automatic samples collected using this method of prepreservation compared to those determined from automatic samples collected under refrigerated conditions. During each site visit, stream water samples contained in each automatic sampler bottle were composited in a decontaminated plastic churn splitter. Subsamples were then withdrawn to analyze for $\mathrm{TP}, \mathrm{TKN}$, and $\mathrm{NO}_{2}+\mathrm{NO}_{3}$ and automatic sampler bottles were replaced with a set of decontaminated bottles.

During each site visit, field readings of water temperature, specific conductance, dissolved-oxygen concentration, and $\mathrm{pH}$ were made using calibrated instruments. Field meters were calibrated according to USGS techniques and a record of field meter calibration, calibration verification, and maintenance was kept in accordance with USGS procedures (U.S. Geological Survey, variously dated). Calibration acceptance criteria are provided in table 2 .

\section{Analytical Methods}

The USGS analytical methods in table 3 are based on corresponding U.S. Environmental Protection Agency (USEPA) methods. Analyses were conducted at USGS laboratories located in Ocala, Fla. (2004-2005) and in Denver, Colorado (2006-2008), and at a TestAmerica laboratory in Tallahassee, Fla. (2006-2008).

\section{Quality-Control Sampling and Requirements}

There were nine types of quality-control samples collected for the study. The quality-control requirements for these samples are described in table 4. Field techniques for sampling were performed according to USGS protocol (U.S. Geological Survey, variously dated).

Table 2. Calibration acceptance criteria for field measurements.

[Calibration frequency was daily in the field; \pm , plus or minus the value; $>$, greater than the value; $\mu \mathrm{S} / \mathrm{cm}$, microsiemens per centimeter; $\leq$, less than or equal to the value; $\mathrm{mg} / \mathrm{L}$, milligrams per liter]

\begin{tabular}{lcc}
\hline \multicolumn{1}{c}{ Parameter } & Calibration & Acceptance criteria \\
\hline Specific conductance & At least 2 standards, bracketing & \pm 3 percent if $>100 \mu \mathrm{S} / \mathrm{cm}$ \\
& expected values & \pm 5 percent if $\leq 100 \mu \mathrm{S} / \mathrm{cm}$ \\
$\mathrm{pH}$ & $\begin{array}{c}\text { Two-point calibration, } \\
\text { bracketing expected values }\end{array}$ & $\pm 0.2 \mathrm{pH}$ units \\
& Air calibration chamber in air & $\pm 0.3 \mathrm{mg} / \mathrm{L}$ or \pm 5 percent, \\
Dissolved oxygen & & whichever is less \\
& &
\end{tabular}

Table 3. Analytical methods prescribed for water-quality constituents.

[USGS, U.S. Geological Survey; USEPA, U.S. Environmental Protection Agency; mg/L, milligrams per liter; LL, low-level analysis performed]

\begin{tabular}{lllc}
\hline \multicolumn{1}{c}{ Constituent } & $\begin{array}{c}\text { USGS analytical } \\
\text { method identifier }\end{array}$ & $\begin{array}{c}\text { Corresponding } \\
\text { USEPA method }\end{array}$ & $\begin{array}{c}\text { Method } \\
\text { detection limit } \\
\text { (mg/L) }\end{array}$ \\
\hline Total organic plus ammonia nitrogen & Not applicable & 351.2 & 0.2 \\
Total nitrite plus nitrate nitrogen & I-4545-85 (LL) & 353.2 & 0.002 \\
Total phosphorus & I-4600-85 (LL) & 365.1 & 0.002 \\
Dissolved ammonia nitrogen & I-2522-90 (LL) & Not applicable & 0.002 \\
Dissolved phosphorus & I-2600-85 (LL) & 365.1 & 0.002 \\
Dissolved ortho-phosphate phosphorus & I-2601-90 (LL) & 365.1 & 0.001 \\
Total suspended solids & I-3765-85 & $160.2 \mathrm{a}$ & 1 \\
\hline
\end{tabular}




\section{Load Calculation Procedures}

Weekly loads for TP, $\mathrm{TKN}$, and $\mathrm{NO}_{2}+\mathrm{NO}_{3}$, are calculated from the flow-weighted composite concentration data, by multiplying the weekly composite concentration by the volume of streamflow that passed the automatic sampling point during the week:

$$
L=K V_{c} C_{f}
$$

where

$L \quad$ is load in MT;

$\mathrm{K}$ is $1 \times 10^{-9}$, the conversion factor for milligrams to MT,

$V_{c} \quad$ is the weekly cumulative streamflow volume in liters, and

$C_{f} \quad$ is the weekly flow-weighted mean concentration in $\mathrm{mg} / \mathrm{L}$.

Concentration values are missing during some periods due to equipment failure, outliers, and extreme flooding when the gage(s) could not be reached. In general, nutrient load was not calculated for the brief periods when concentration values were missing. This methodology was revised in the 2008 water year (Water year is the period between October 1 and September 30 and is defined by the year in which the period ends. For example, the 2008 water year is October 1, 2007 through September 30, 2008.) to estimate the periods when nutrient concentration was not measured. For these periods, nutrient concentration was estimated by averaging the measured concentration from the previous week and the week following the missing concentration value.

Loads for dissolved phosphorus, dissolved orthophosphate phosphorus, dissolved ammonia nitrogen, and total suspended solids are calculated as instantaneous loads. That is, the constituent concentration from the manual sample is multiplied by the flow at the time the sample is collected. Therefore, these loads are "point" or "instantaneous" loads and are flagged (U.S. Geological Survey, 2011) to differentiate them from loads calculated from the flow-weighted composite samples.

\section{Nutrient Loads}

\section{Discharge}

Monthly mean, maximum, and minimum discharge was determined for all tributary sites in the Lake Okeechobee watershed during water years (WY) 2004-2008. Annual and seasonal discharge is dependent upon rainfall (fig. 3). The hurricane-influenced years of 2004, 2005, and the latter part of 2008 , had substantially greater flows than the drought years of

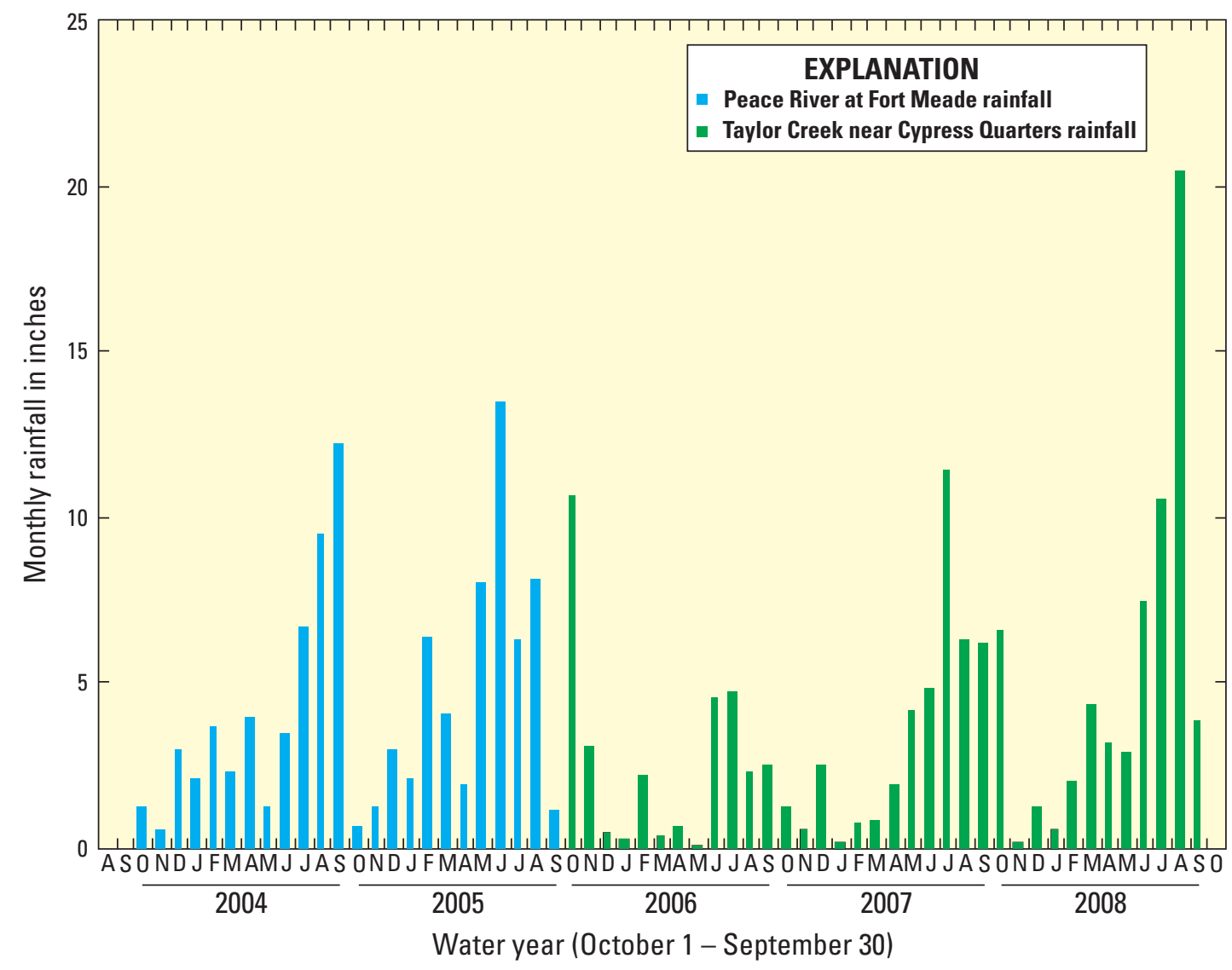

Figure 3. Monthly rainfall measured at Peace River at Fort Meade, and at Taylor Creek near Cypress Quarters, Florida. 
2006 and 2007. Discharge was greatest on the western side of the Kissimmee River due to the larger basins (fig. 2). The nonpriority basins annually contribute 5 to 6 times more discharge than the priority basins (table 5). Plots of monthly mean discharge from the tributaries east and west of the Kissimmee River are shown in figures 4 and 5, respectively.

Total annual discharge in the priority basins ranged from 41,000 (WY2007) to 219,000 (WY2005) acre-ft (table 5). Total annual discharge is greatest in Taylor Creek, Williamson Ditch, and L63 Interceptor, and lowest in Wolff Creek.

Total annual discharge in the non-priority basins ranged from 245,000 (WY2007) to 1,322,000 (WY2005) acre-ft (table 5). Discharge was highest at C41A Canal, Fisheating Creek at Palmdale, and Arbuckle Creek, and was lowest at Fisheating Creek at Lake Placid.

\section{Nutrient Concentrations}

Nutrient concentrations were determined for all tributaries in the Lake Okeechobee watershed during WY 2004-2008. A nonparametric multiple comparison test using the Dunn-Sidak test (Glantz, 2005) was used to statistically test the difference of mean nutrient concentration between tributaries. The smaller the p-value, the more likely the variable is significantly different. For the purpose of the present study, values exceeding 0.05 for independent variables were considered insignificant. Letters were used to group statistically similar tributaries. For example, figure 6 shows that Mosquito Creek and Taylor Creek near Cypress Quarters (group A) have statistically significant greater TP concentration from every tributary with the exception of Nubbin Slough and Popash Slough (group AB) and Taylor Creek near Grassy Island (group $\mathrm{ABC}$ ). Box plots of TP, TKN, $\mathrm{NO}_{2}+\mathrm{NO}_{3}$ concentrations, and the results of the comparative site statistical analyses are presented in figures 6 through 8 , respectively. Descriptive statistics for nutrient concentrations are summarized in table 6.

Mean concentrations of TP ranged from 0.10 to $0.54 \mathrm{mg} / \mathrm{L}$ at the 16 tributaries from WY 2004-2008 (table 6). Mean concentrations were significantly higher in the priority basins and significantly lowest in the non-priority basin sites Arbuckle Creek and C 41A Canal (fig. 6; table 6).

Table 4. Quality-control samples and requirements.

$[\leq$, less than or equal to the value; MDL, method detection limit; $2 \mathrm{x}, 2$ times the value; $<$, less than the value]

\begin{tabular}{|c|c|c|c|}
\hline Quality-control sample & Quality-control requirement & Frequency & Acceptance criteria \\
\hline Autosampler blanks & $\begin{array}{l}\text { Cleaned autosampler tubing is free of } \\
\text { analytes of interest }\end{array}$ & $\begin{array}{l}\text { Four per year (when auto- } \\
\text { sampler tubing is replaced) }\end{array}$ & $\begin{array}{l}\text { Analyte concentrations } \\
\text { are } \leq 2 \mathrm{x} \text { MDL }\end{array}$ \\
\hline $\begin{array}{l}\text { Manual samples from } \\
\text { multiple points in the } \\
\text { cross section, analyzed } \\
\text { with field HACH kits }\end{array}$ & $\begin{array}{l}\text { A well-mixed water-quality measurement } \\
\text { cross section exists at site }\end{array}$ & $\begin{array}{l}\text { One per site prior to } \\
\text { instrumentation }\end{array}$ & $\begin{array}{l}\text { Will be a subjective } \\
\text { determination for each site }\end{array}$ \\
\hline $\begin{array}{l}\text { Verification of autosam- } \\
\text { pler intake samples }\end{array}$ & $\begin{array}{l}\text { Location of the autosampler intake line is } \\
\text { representative of the stream cross } \\
\text { section }\end{array}$ & $\begin{array}{l}1 \text { per site every } 5 \text { samples in } \\
\text { years } 2 \text { and } 3 \text {; one per site } \\
\text { every } 20 \text { samples in subse- } \\
\text { quent years }\end{array}$ & $\begin{array}{l}\text { Will be determined for each site } \\
\text { through statistical testing }\end{array}$ \\
\hline $\begin{array}{l}\text { Tubing inflow/outflow } \\
\text { samples }\end{array}$ & $\begin{array}{l}\text { Sample has not changed during passage } \\
\text { through autosampler tubing }\end{array}$ & $\begin{array}{l}\text { Two per site in year 2; one per } \\
\text { site per year in subsequent } \\
\text { years }\end{array}$ & $\begin{array}{l}\text { All samples "accepted," } \\
\text { but percent relative standard } \\
\text { deviation of }<20 \text { is desired }\end{array}$ \\
\hline $\begin{array}{l}\text { Verification of nutrient } \\
\text { stability samples }\end{array}$ & $\begin{array}{l}\text { Water-quality constituents are stable } \\
\text { for at least } 1 \text { week in unrefrigerated } \\
\text { autosampler bottles }\end{array}$ & $\begin{array}{l}\text { Two per site in year } 2 \text { (in two } \\
\text { different seasons) }\end{array}$ & $\begin{array}{l}\text { All samples "accepted," but } \\
\text { percent relative standard } \\
\text { deviation is }<10 \text { percent }\end{array}$ \\
\hline Split replicate samples & $\begin{array}{l}\text { Constituent concentrations are precise; } \\
\text { variability introduced during laboratory } \\
\text { processing and analysis lies within } \\
\text { acceptable limits }\end{array}$ & One every 20 samples & $\begin{array}{l}\text { Percent relative standard } \\
\text { deviation is }<10 \text { percent }\end{array}$ \\
\hline
\end{tabular}



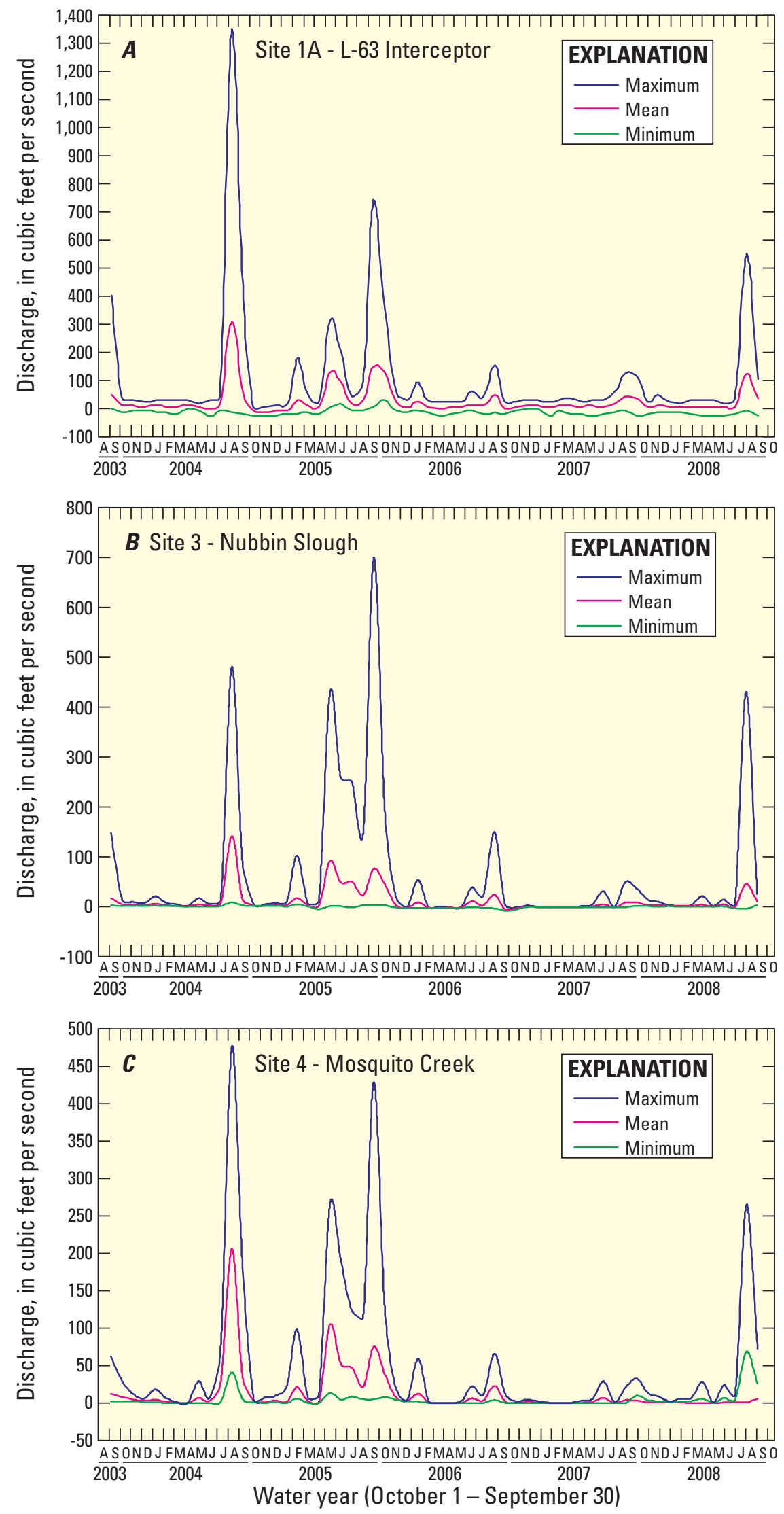

Figure 4. Monthly discharge at sites east of the Kissimmee River in Florida. Site locations are shown in figure 2. 

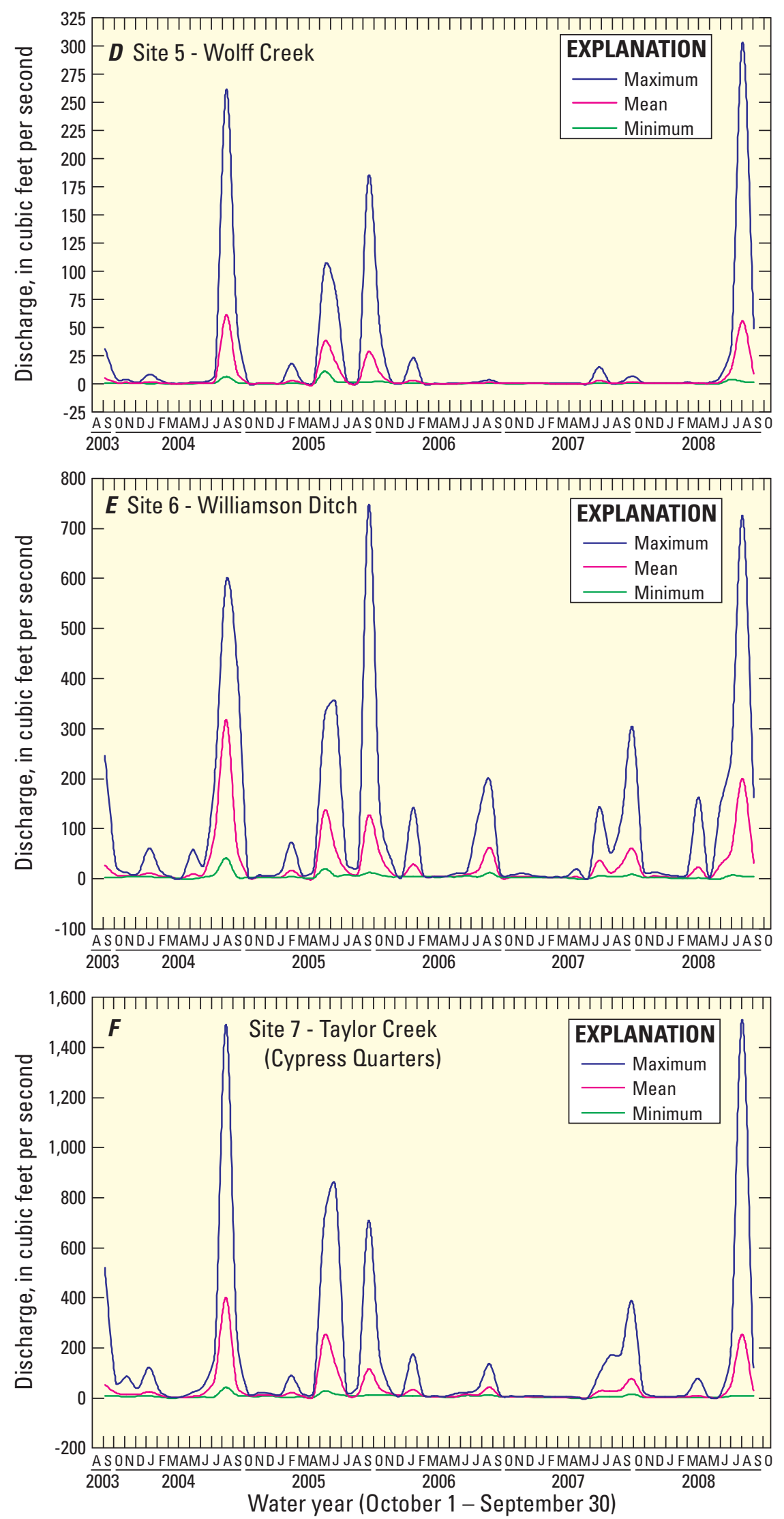

Figure 4. Monthly discharge at sites east of the Kissimmee River in Florida.

Site locations are shown in figure 2.-Continued. 

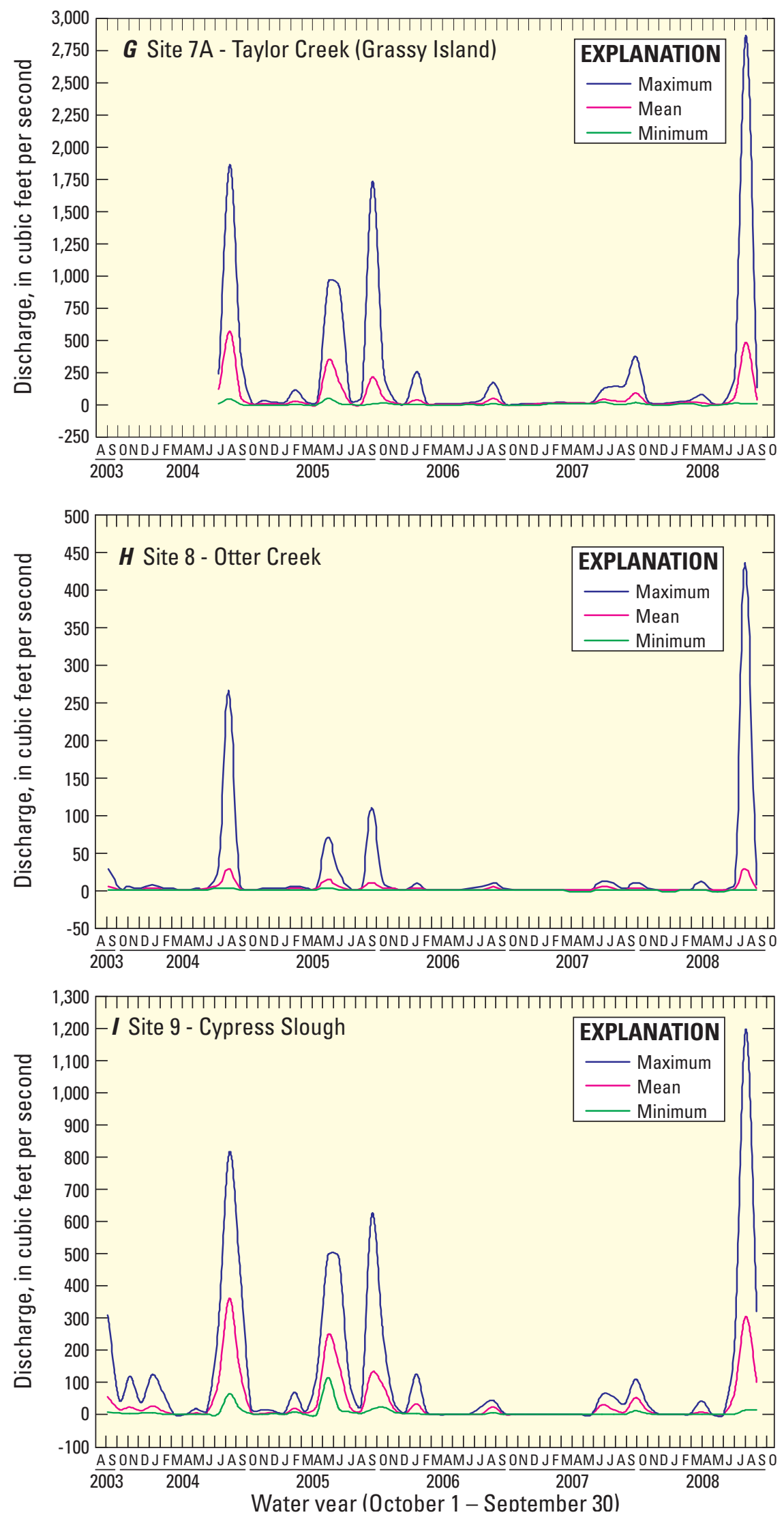

Figure 4. Monthly discharge at sites east of the Kissimmee River in Florida. Site locations are shown in figure 2.-Continued. 

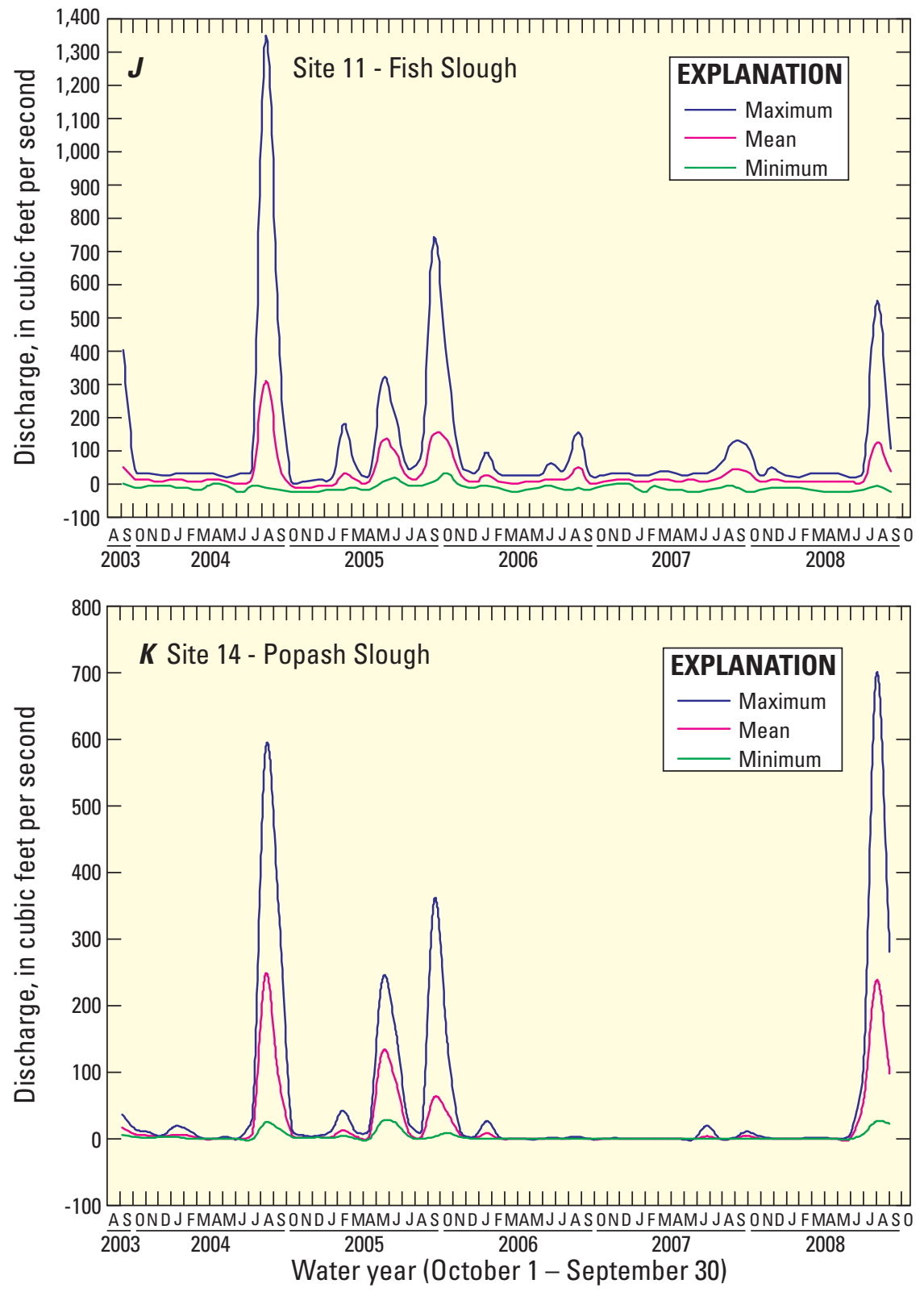

Figure 4. Monthly discharge at sites east of the Kissimmee River in Florida. Site locations are shown in figure 2.-Continued. 

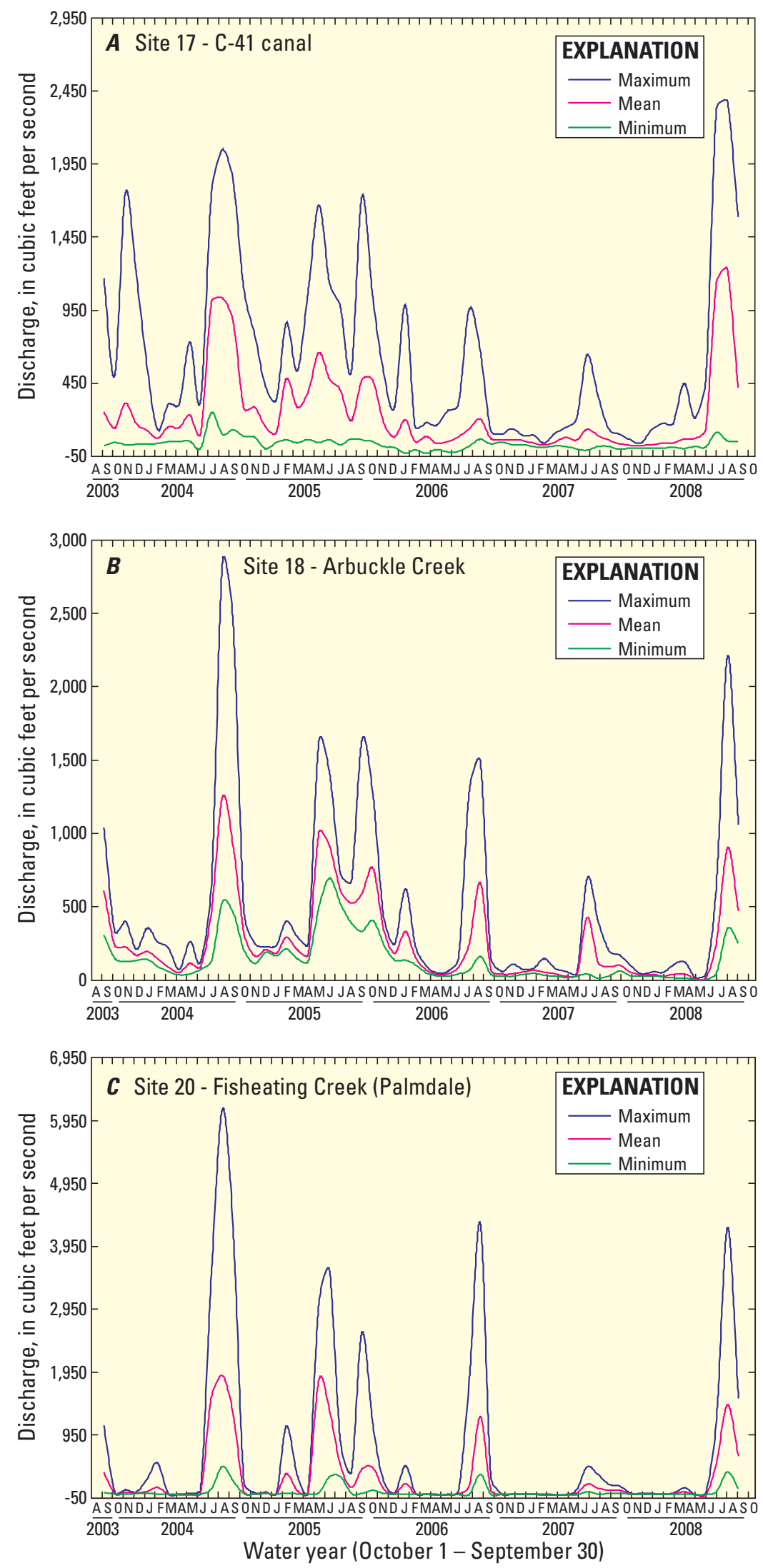

Figure 5. Monthly discharge at sites west of the Kissimmee River in Florida. Site locations are shown in figure 2. 

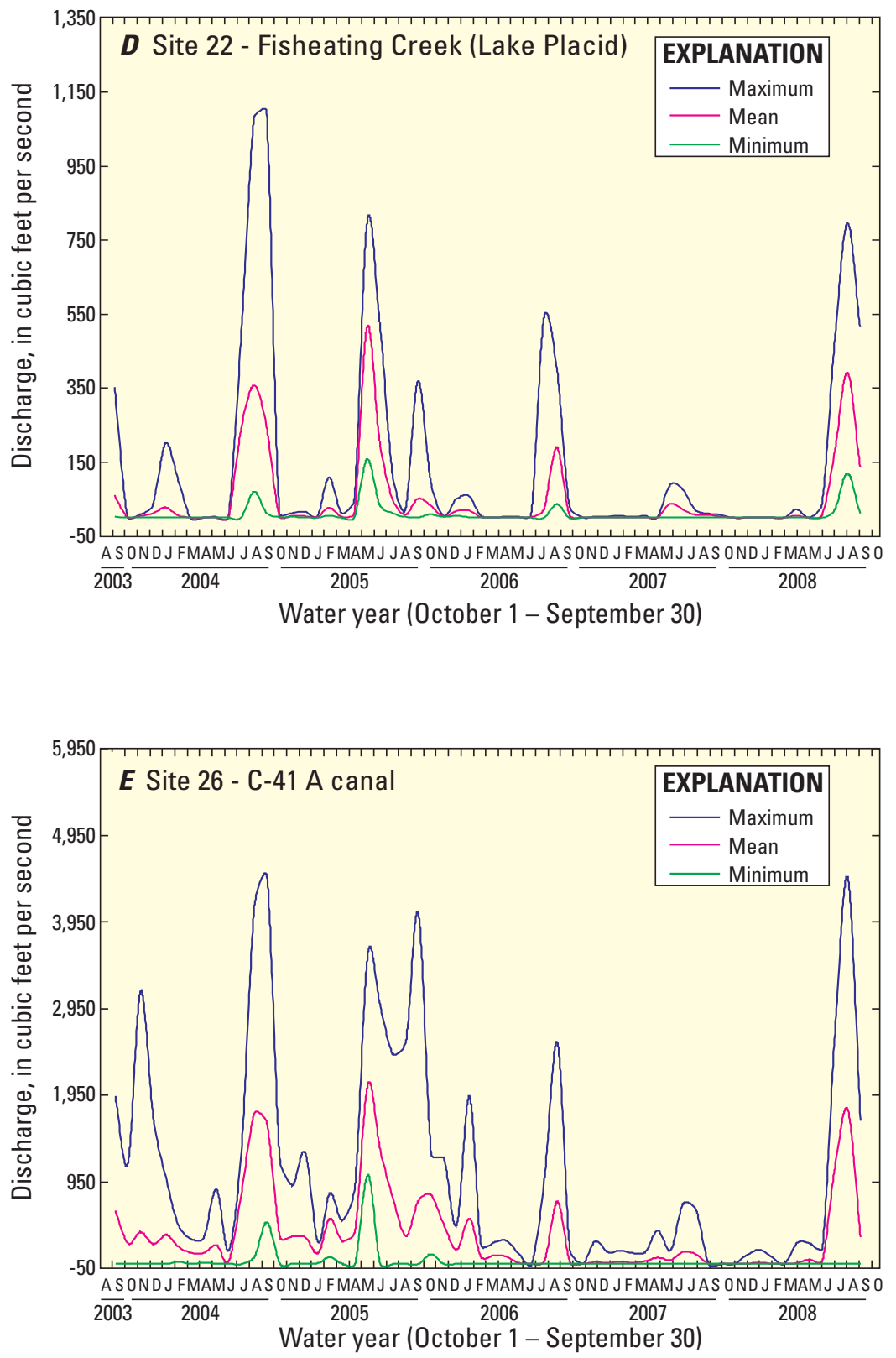

Figure 5. Monthly discharge at sites west of the Kissimmee River in Florida. Site locations are shown in figure 2.-Continued 
Mean concentrations of TKN ranged from 1.27 to $2.96 \mathrm{mg} / \mathrm{L}$ at the 16 tributaries from WY 2004-2008 (table 6). Mean TKN concentration was highest in the non-priority basin site at Fisheating Creek at Lake Placid (fig.7; table 6) and lowest at the priority basin sites at Wolff Creek, Taylor Creek near Grassy Island, Otter Creek, and at the non-priority basin site at Arbuckle Creek (fig. 7; table 6).

Mean concentrations of $\mathrm{NO}_{2}+\mathrm{NO}_{3}$ ranged from 0.01 to $0.55 \mathrm{mg} / \mathrm{L}$ at the 16 tributaries during WY 2004-2008 (table 6). Mean concentrations of $\mathrm{NO}_{2}+\mathrm{NO}_{3}$ were significantly highest in the priority basins and significantly lower in the non-priority basins (fig. 8; table 6).

\section{Computation of Loads}

Annual nutrient loads are summations of weekly loads that were measured with a flow-weighted composite sampler and then multiplied by discharge. Nutrient loads were substantially higher in the non-priority basins west of the Kissimmee River because discharge in the non-priority basins is 5 to 6 times greater than the priority basins (table 5). Loading of
$\mathrm{TP}, \mathrm{TKN}$, and $\mathrm{NO}_{2}+\mathrm{NO}_{3}$ was $1.5,4.5$, and 3.5 times greater, respectively, in the non-priority basins (table 7 ).

In the non-priority basins, TP loads ranged from $35 \mathrm{MT}$ (WY2007) to 247 MT (WY2005; table 7). The TP loads were relatively evenly distributed between tributaries. In the priority basins, the TP loads ranged from 18 MT (WY2007) to $136 \mathrm{MT}$ (WY2005; table 7). The highest TP loads were $72 \mathrm{MT}$ in Fisheating Creek at Palmdale (WY2004), and lowest 0.1 MT in Wolff Creek (WY2007; table 7).

In the non-priority basins, TKN loads ranged from 337 MT (WY2007) to 2,817 MT (WY2005; table 7). In the priority basins, TKN loads ranged from $85 \mathrm{MT}$ (WY2007) to 503 MT (WY2005; table 7). The TKN loads were relatively distributed between the tributaries, with loads being highest 774 MT in C41 Canal (WY2005) and lowest 1 MT in Wolff Creek (WY2007).

In the non-priority basins, $\mathrm{NO}_{2}+\mathrm{NO}_{3}$ loads ranged from 34 MT (WY2006 and 2007) to 143 MT (WY2005; table 7). In the priority basins, $\mathrm{NO}_{2}+\mathrm{NO}_{3}$ loads ranged from $4 \mathrm{MT}$ in WY2007 to $27 \mathrm{MT}$ in WY2005 (table 7). The $\mathrm{NO}_{2}+\mathrm{NO}_{3}$ highest loads were 87 MT in C-41 Canal in WY2005 to and lowest less than 0.01 MT in Popash Slough in WY2007.

Table 5. Summary of annual discharge in the Lake Okeechobee watershed, water years 2004-2008.

[Taylor Creek near Cypress Quarters and Fisheating Creek at Lake Placid are the upstream sites and they are not included in the summation, except in 2004, because the Taylor Creek gaging station at Grassy Island was not built; values are shown in acre-feet; —, no data]

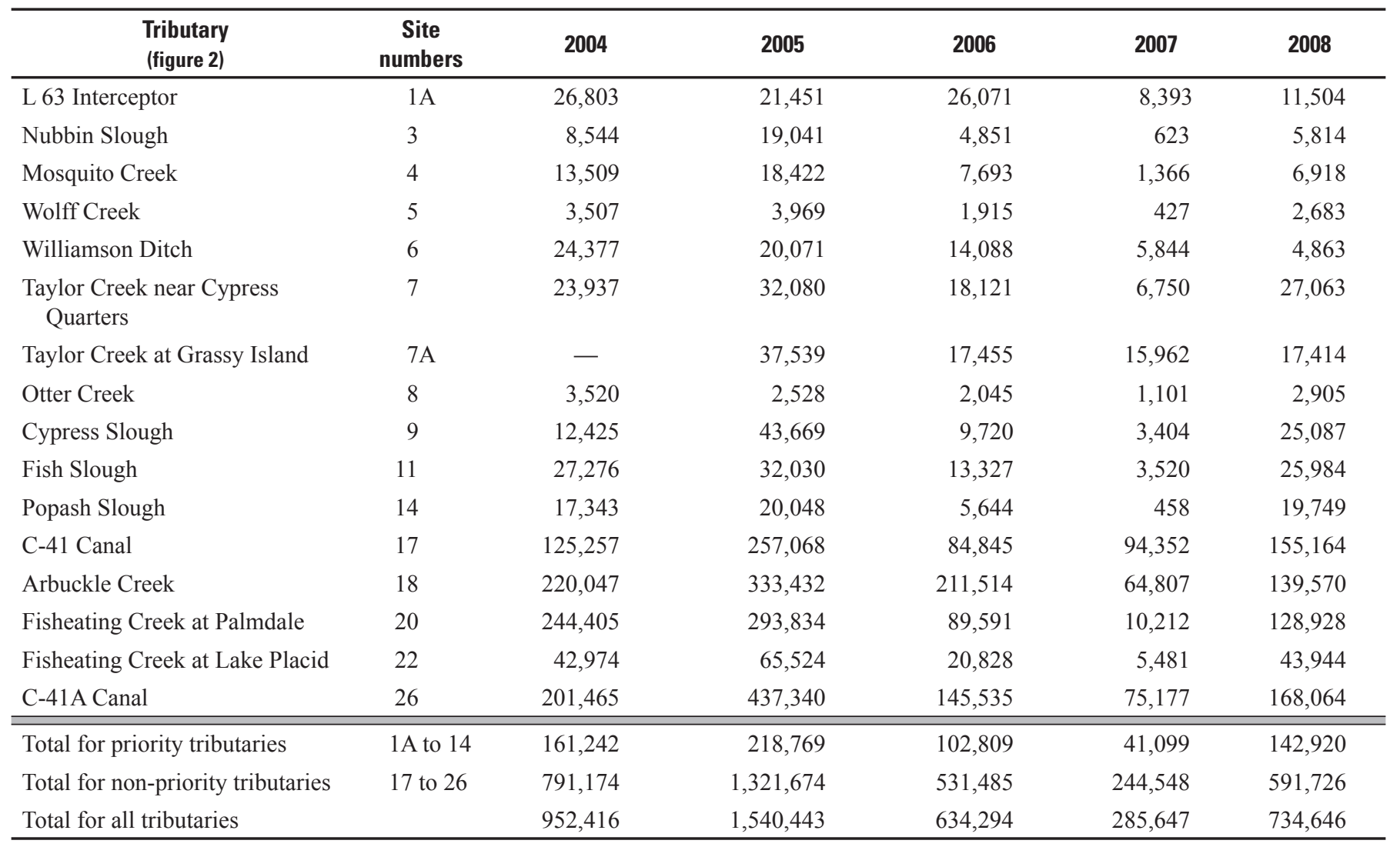




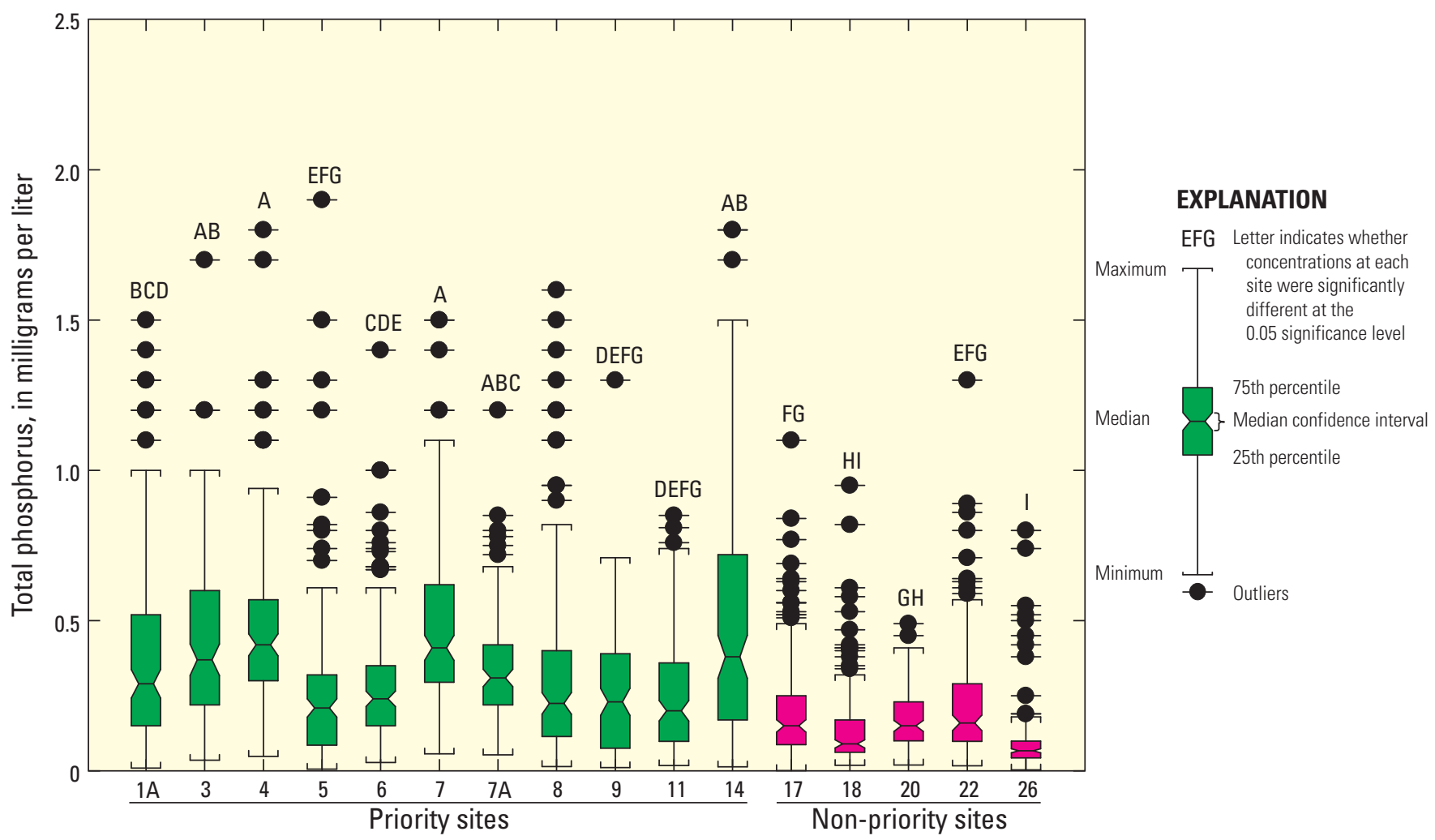

Figure 6. Total phosphorus concentrations by site for water years 2004-2008 in south-central Florida. Median values with the same letter were not statistically different. Letters are used to group sites by concentration; sites that do not share letters are significantly different at the 0.05 significance level.

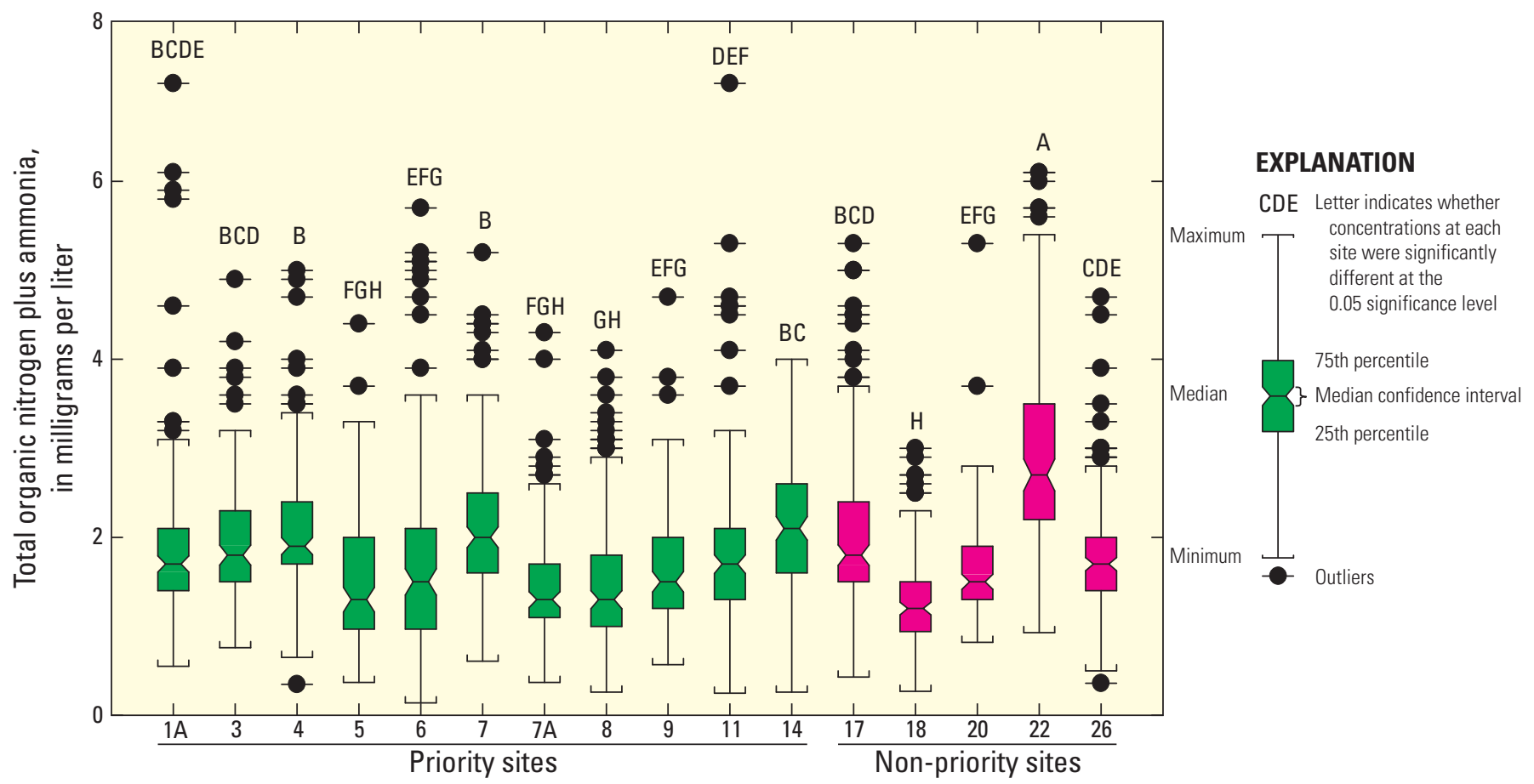

Figure 7. Total organic nitrogen plus ammonia concentrations by site for water years 2004-2008 in south-central Florida. Median values with the same letter were not statistically different. Letters are used to group sites by concentration; sites that do not share letters are significantly different at the 0.05 significance level. 
Table 6. Statistical analysis of nutrient concentrations in the Lake Okeechobee watershed, water years 2004-2008.

[Nutrient: TP, total phosphorus; TKN, total organic nitrogen plus ammonia; $\mathrm{NO}_{2}+\mathrm{NO}_{3}$, total nitrite plus nitrate; values are shown in milligrams per liter]

\begin{tabular}{|c|c|c|c|c|c|c|c|c|}
\hline $\begin{array}{l}\text { Tributary } \\
\text { (figure 2) }\end{array}$ & $\begin{array}{c}\text { Site } \\
\text { numbers }\end{array}$ & Nutrient & $\begin{array}{c}\text { Number of } \\
\text { samples }\end{array}$ & Mean & $\begin{array}{l}\text { Standard } \\
\text { deviation }\end{array}$ & Minimum & Median & Maximum \\
\hline \multirow{3}{*}{ L 63 Interceptor } & \multirow{3}{*}{$1 \mathrm{~A}$} & TP & 150 & 0.38 & 0.31 & 0.010 & 0.29 & 1.50 \\
\hline & & TKN & 147 & 1.92 & 0.94 & 0.55 & 1.700 & 7.10 \\
\hline & & $\mathrm{NO}_{2}+\mathrm{NO}_{3}$ & 145 & 0.09 & 0.10 & 0.00 & 0.047 & 0.49 \\
\hline \multirow{3}{*}{ Nubbin Slough } & \multirow{3}{*}{3} & TP & 127 & 0.44 & 6.29 & 0.036 & 0.38 & 1.70 \\
\hline & & TKN & 127 & 2.05 & 0.93 & 0.760 & 1.90 & 9.10 \\
\hline & & $\mathrm{NO}_{2}+\mathrm{NO}_{3}$ & 127 & 0.48 & 0.53 & 0.005 & 0.34 & 2.70 \\
\hline \multirow{3}{*}{ Mosquito Creek } & \multirow{3}{*}{4} & $\mathrm{TP}$ & 134 & 0.54 & 0.46 & 0.049 & 0.43 & 3.60 \\
\hline & & TKN & 134 & 2.30 & 1.22 & 0.350 & 2.00 & 9.10 \\
\hline & & $\mathrm{NO}_{2}+\mathrm{NO}_{3}$ & 134 & 0.31 & 0.28 & 0.006 & 0.21 & 1.50 \\
\hline \multirow{3}{*}{ Wolff Creek } & \multirow{3}{*}{5} & $\mathrm{TP}$ & 130 & 0.28 & 0.28 & 0.006 & 0.21 & 1.90 \\
\hline & & $\mathrm{TKN}$ & 130 & 1.60 & 0.88 & 0.370 & 1.35 & 6.70 \\
\hline & & $\mathrm{NO}_{2}+\mathrm{NO}_{3}$ & 130 & 0.07 & 0.12 & 0.001 & 0.02 & 0.65 \\
\hline \multirow{3}{*}{ Williamson Ditch } & \multirow{3}{*}{6} & $\mathrm{TP}$ & 143 & 0.31 & 0.25 & 0.028 & 0.25 & 1.90 \\
\hline & & TKN & 143 & 1.91 & 1.59 & 0.140 & 1.60 & 12.00 \\
\hline & & $\mathrm{NO}_{2}+\mathrm{NO}_{3}$ & 143 & 0.08 & 0.07 & 0.002 & 0.06 & 0.54 \\
\hline \multirow{3}{*}{$\begin{array}{l}\text { Taylor Creek near } \\
\text { Cypress Quarters }\end{array}$} & \multirow{3}{*}{7} & $\mathrm{TP}$ & 155 & 0.54 & 0.36 & 0.057 & 0.43 & 1.90 \\
\hline & & TKN & 155 & 2.79 & 3.47 & 0.610 & 2.10 & 34.00 \\
\hline & & $\mathrm{NO}_{2}+\mathrm{NO}_{3}$ & 155 & 0.55 & 0.43 & 0.001 & 0.41 & 1.60 \\
\hline \multirow{3}{*}{$\begin{array}{l}\text { Taylor Creek at } \\
\text { Grassy Island }\end{array}$} & \multirow{3}{*}{$7 \mathrm{~A}$} & $\mathrm{TP}$ & 113 & 0.35 & 0.19 & 0.054 & 0.31 & 1.20 \\
\hline & & TKN & 113 & 1.56 & 0.89 & 0.370 & 1.30 & 8.00 \\
\hline & & $\mathrm{NO}_{2}+\mathrm{NO}_{3}$ & 113 & 0.26 & 0.24 & 0.003 & 0.15 & 0.89 \\
\hline \multirow{3}{*}{ Otter Creek } & \multirow{3}{*}{8} & $\mathrm{TP}$ & 160 & 0.32 & 0.31 & 0.02 & 0.230 & 1.60 \\
\hline & & $\mathrm{TKN}$ & 153 & 1.53 & 0.76 & 0.26 & 1.300 & 4.10 \\
\hline & & $\mathrm{NO}_{2}+\mathrm{NO}_{3}$ & 160 & 0.21 & 0.18 & 0.00 & 0.160 & 0.70 \\
\hline \multirow{3}{*}{ Cypress Slough } & \multirow{3}{*}{9} & $\mathrm{TP}$ & 113 & 0.26 & 0.21 & 0.011 & 0.23 & 1.30 \\
\hline & & $\mathrm{TKN}$ & 113 & 1.64 & 0.65 & 0.570 & 1.50 & 4.70 \\
\hline & & $\mathrm{NO}_{2}+\mathrm{NO}_{3}$ & 113 & 0.08 & 0.33 & 0.000 & 0.02 & 3.40 \\
\hline \multirow{3}{*}{ Fish Slough } & \multirow{3}{*}{11} & $\mathrm{TP}$ & 148 & 0.26 & 0.19 & 0.200 & 0.02 & 0.85 \\
\hline & & TKN & 146 & 1.84 & 0.96 & 0.25 & 1.700 & 7.10 \\
\hline & & $\mathrm{NO}_{2}+\mathrm{NO}_{3}$ & 142 & 0.06 & 0.09 & 0.00 & 0.028 & 0.51 \\
\hline \multirow{3}{*}{ Popash Slough } & \multirow{3}{*}{14} & TP & 135 & 0.50 & 0.40 & 0.014 & 0.38 & 1.80 \\
\hline & & $\mathrm{TKN}$ & 135 & 2.05 & 0.73 & 0.260 & 2.00 & 4.00 \\
\hline & & $\mathrm{NO}_{2}+\mathrm{NO}_{3}$ & 135 & 0.03 & 0.05 & 0.001 & 0.01 & 0.45 \\
\hline
\end{tabular}


Table 6. Statistical analysis of nutrient concentrations in the Lake Okeechobee watershed, water years 2004-2008. —Continued [Nutrient: TP, total phosphorus; TKN, total organic nitrogen plus ammonia; $\mathrm{NO}_{2}+\mathrm{NO}_{3}$, total nitrite plus nitrate; values are shown in milligrams per liter]

\begin{tabular}{|c|c|c|c|c|c|c|c|c|}
\hline $\begin{array}{l}\text { Tributary } \\
\text { (figure 2) }\end{array}$ & $\begin{array}{c}\text { Site } \\
\text { numbers }\end{array}$ & Nutrient & $\begin{array}{c}\text { Number of } \\
\text { samples }\end{array}$ & Mean & $\begin{array}{l}\text { Standard } \\
\text { deviation }\end{array}$ & Minimum & Median & Maximum \\
\hline \multirow{3}{*}{ C-41 Canal } & \multirow{3}{*}{17} & $\mathrm{TP}$ & 143 & 0.20 & 0.17 & 0.008 & 0.15 & 1.10 \\
\hline & & TKN & 143 & 1.99 & 0.88 & 0.430 & 1.80 & 5.30 \\
\hline & & $\mathrm{NO}_{2}+\mathrm{NO}_{3}$ & 143 & 0.19 & 0.21 & 0.002 & 0.11 & 1.10 \\
\hline \multirow{3}{*}{ Arbuckle Creek } & \multirow{3}{*}{18} & $\mathrm{TP}$ & 155 & 0.14 & 0.14 & 0.02 & 0.090 & 0.95 \\
\hline & & TKN & 153 & 1.27 & 0.52 & 0.27 & 1.200 & 3.00 \\
\hline & & $\mathrm{NO}_{2}+\mathrm{NO}_{3}$ & 155 & 0.17 & 0.19 & 0.00 & 0.110 & 0.95 \\
\hline \multirow{3}{*}{$\begin{array}{l}\text { Fisheating Creek at } \\
\text { Palmdale }\end{array}$} & \multirow{3}{*}{20} & $\mathrm{TP}$ & 115 & 0.18 & 0.09 & 0.020 & 0.16 & 0.49 \\
\hline & & TKN & 115 & 1.62 & 0.54 & 0.820 & 1.50 & 5.30 \\
\hline & & $\mathrm{NO}_{2}+\mathrm{NO}_{3}$ & 115 & 0.04 & 0.04 & 0.001 & 0.03 & 0.30 \\
\hline \multirow{3}{*}{$\begin{array}{l}\text { Fisheating Creek at } \\
\text { Lake Placid }\end{array}$} & \multirow{3}{*}{22} & $\mathrm{TP}$ & 134 & 0.23 & 0.20 & 0.02 & 0.160 & 1.30 \\
\hline & & TKN & 131 & 2.96 & 1.17 & 0.93 & 2.700 & 6.10 \\
\hline & & $\mathrm{NO}_{2}+\mathrm{NO}_{3}$ & 130 & 0.03 & 0.04 & 0.00 & 0.018 & 0.34 \\
\hline \multirow{3}{*}{ C-41A Canal } & \multirow{3}{*}{26} & $\mathrm{TP}$ & 147 & 0.10 & 0.12 & 0.004 & 0.07 & 0.80 \\
\hline & & TKN & 147 & 1.79 & 0.69 & 0.360 & 1.70 & 4.70 \\
\hline & & $\mathrm{NO}_{2}+\mathrm{NO}_{3}$ & 147 & 0.01 & 0.02 & 0.001 & 0.01 & 0.11 \\
\hline
\end{tabular}

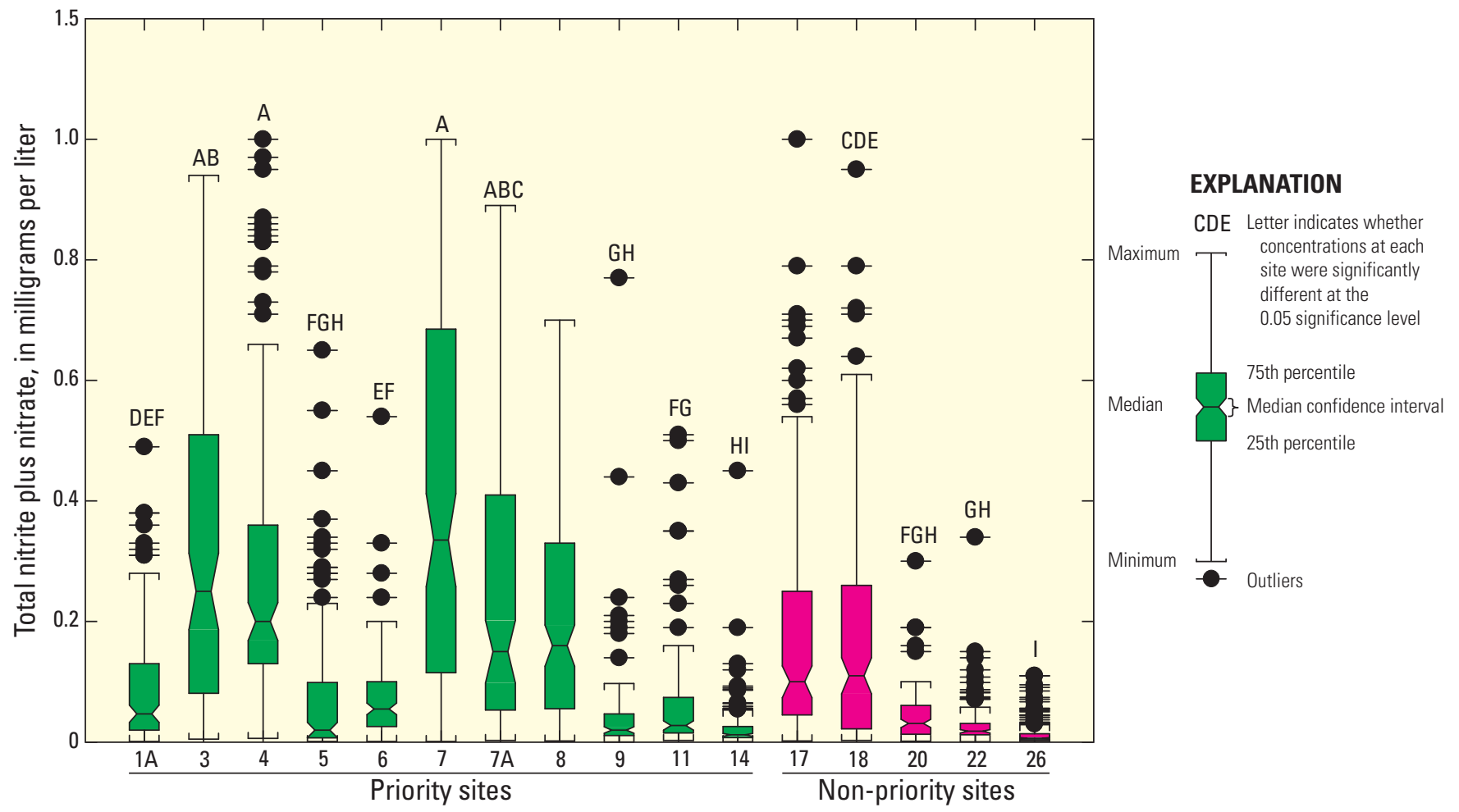

Figure 8. Total nitrite plus nitrate concentrations by site for water years 2004-2008 in south-central Florida. Median values with the same letter were not statistically different. Letters are used to group sites by concentration; sites that do not share letters are significantly different at the 0.05 significance level. 
Table 7. Summary of annual nutrient loads in the Lake Okeechobee watershed, water years 2004-2008.

[Taylor Creek near Cypress Quarters and Fisheating Creek at Lake Placid are upstream sites and are excluded from the summation; values are shown in metric tons; Nutrient: $\mathrm{TKN}$, total organic nitrogen plus ammonia; $\mathrm{NO}_{2}+\mathrm{NO}_{3}$, total nitrite plus nitrate; 一, no data]

\begin{tabular}{|c|c|c|c|c|c|c|c|}
\hline $\begin{array}{l}\text { Tributary } \\
\text { (figure 2) }\end{array}$ & $\begin{array}{c}\text { Site } \\
\text { numbers }\end{array}$ & Nutrient & 2004 & 2005 & 2006 & 2007 & 2008 \\
\hline \multirow{3}{*}{ L 63 Interceptor } & \multirow{3}{*}{$1 \mathrm{~A}$} & $\mathrm{TP}$ & 21.72 & 17.32 & 16.64 & 0.76 & 11.91 \\
\hline & & TKN & 56.24 & 53.32 & 40.71 & 3.34 & 28.46 \\
\hline & & $\mathrm{NO}_{2}+\mathrm{NO}_{3}$ & 0.79 & 1.40 & 1.08 & 0.46 & 0.19 \\
\hline \multirow{3}{*}{ Nubbin Slough } & \multirow{3}{*}{3} & $\mathrm{TP}$ & 8.04 & 13.86 & 3.16 & 0.23 & 4.44 \\
\hline & & TKN & 21.53 & 53.94 & 8.66 & 0.87 & 14.88 \\
\hline & & $\mathrm{NO}_{2}+\mathrm{NO}_{3}$ & 3.95 & 6.58 & 1.98 & -0.34 & 0.78 \\
\hline \multirow{3}{*}{ Mosquito Creek } & \multirow{3}{*}{4} & $\mathrm{TP}$ & 14.40 & 16.23 & 4.31 & 0.98 & 5.99 \\
\hline & & TKN & 36.27 & 54.99 & 11.30 & 2.67 & 18.43 \\
\hline & & $\mathrm{NO}_{2}+\mathrm{NO}_{3}$ & 1.24 & 4.67 & 1.83 & 0.40 & 1.01 \\
\hline \multirow{3}{*}{ Wolff Creek } & \multirow{3}{*}{5} & TP & 2.14 & 2.32 & 0.52 & 0.10 & 1.57 \\
\hline & & TKN & 9.91 & 12.92 & 2.40 & 0.76 & 14.50 \\
\hline & & $\mathrm{NO}_{2}+\mathrm{NO}_{3}$ & 0.07 & 0.44 & 0.11 & 0.01 & 0.20 \\
\hline \multirow{3}{*}{ Williamson Ditch } & \multirow{3}{*}{6} & $\mathrm{TP}$ & 12.86 & 7.31 & 3.92 & 1.68 & 6.62 \\
\hline & & TKN & 64.39 & 46.75 & 22.34 & 9.55 & 38.90 \\
\hline & & $\mathrm{NO}_{2}+\mathrm{NO}_{3}$ & 0.74 & 1.43 & 1.03 & 0.63 & 0.70 \\
\hline \multirow{3}{*}{ Taylor Creek near Cypress Quarters } & \multirow{3}{*}{7} & $\mathrm{TP}$ & 14.21 & 32.96 & 7.07 & 9.79 & 10.67 \\
\hline & & TKN & 82.43 & 158.85 & 28.01 & 34.03 & 40.18 \\
\hline & & $\mathrm{NO}_{2}+\mathrm{NO}_{3}$ & 4.29 & 12.40 & 6.63 & 4.54 & 9.02 \\
\hline \multirow{3}{*}{ Taylor Creek at Grassy Island ${ }^{1}$} & \multirow{3}{*}{$7 \mathrm{~A}$} & TP & - & 25.62 & 9.06 & 8.72 & 8.66 \\
\hline & & TKN & - & 80.29 & 26.21 & 31.05 & 27.16 \\
\hline & & $\mathrm{NO}_{2}+\mathrm{NO}_{3}$ & - & 6.59 & 4.77 & 2.17 & 1.46 \\
\hline \multirow{3}{*}{ Otter Creek } & \multirow{3}{*}{8} & $\mathrm{TP}$ & 3.30 & 1.93 & 0.70 & 2.61 & 2.50 \\
\hline & & TKN & 11.05 & 6.05 & 2.89 & 18.78 & 8.19 \\
\hline & & $\mathrm{NO}_{2}+\mathrm{NO}_{3}$ & 0.93 & 0.83 & 0.77 & 0.15 & 0.48 \\
\hline \multirow{3}{*}{ Cypress Slough } & \multirow{3}{*}{9} & $\mathrm{TP}$ & 9.00 & 19.10 & 3.41 & 1.40 & 11.81 \\
\hline & & TKN & 46.62 & 61.08 & 14.76 & 9.11 & 41.52 \\
\hline & & $\mathrm{NO}_{2}+\mathrm{NO}_{3}$ & 0.37 & 1.95 & 0.05 & 0.21 & 0.68 \\
\hline \multirow{3}{*}{ Fish Slough } & \multirow{3}{*}{11} & TP & 24.55 & 14.95 & 5.56 & 1.18 & 7.32 \\
\hline & & TKN & 62.37 & 71.45 & 23.62 & 8.40 & 40.21 \\
\hline & & $\mathrm{NO}_{2}+\mathrm{NO}_{3}$ & 1.14 & 3.09 & 2.96 & 0.10 & 1.18 \\
\hline
\end{tabular}


Table 7. Summary of annual nutrient loads in the Lake Okeechobee watershed, water years 2004-2008. —Continued

[Taylor Creek near Cypress Quarters and Fisheating Creek at Lake Placid are upstream sites and are excluded from the summation; values are shown in metric tons; Nutrient: TKN, total organic nitrogen plus ammonia; $\mathrm{NO}_{2}+\mathrm{NO}_{3}$, total nitrite plus nitrate; -, no data]

\begin{tabular}{|c|c|c|c|c|c|c|c|}
\hline $\begin{array}{c}\text { Tributary } \\
\text { (figure 2) }\end{array}$ & $\begin{array}{c}\text { Site } \\
\text { numbers }\end{array}$ & Nutrient & 2004 & 2005 & 2006 & 2007 & 2008 \\
\hline \multirow{2}{*}{ Popash Slough } & \multirow{2}{*}{14} & $\mathrm{TP}$ & 14.60 & 17.31 & 4.34 & 0.21 & 25.63 \\
\hline & & $\mathrm{NO}_{2}+\mathrm{NO}_{3}$ & 0.06 & 0.41 & 0.05 & 0.00 & 0.33 \\
\hline C-41 Canal & 17 & $\mathrm{TP}$ & 30.74 & 58.12 & 16.12 & 20.35 & 39.52 \\
\hline \multirow{3}{*}{ Arbuckle Creek } & \multirow{3}{*}{18} & $\mathrm{TP}$ & 44.85 & 62.72 & 33.65 & 7.99 & 23.21 \\
\hline & & TKN & 328.94 & 471.76 & 243.47 & 84.17 & 201.60 \\
\hline & & $\mathrm{NO}_{2}+\mathrm{NO}_{3}$ & 28.76 & 21.64 & 14.93 & 21.28 & 5.20 \\
\hline Fisheating Creek at Palmdale & 20 & $\mathrm{TP}$ & 71.76 & 65.80 & 9.79 & 2.12 & 44.62 \\
\hline \multirow[t]{2}{*}{ Fisheating Creek at Lake Placid } & \multirow[t]{2}{*}{22} & TKN & 244.96 & 397.63 & 40.41 & 36.40 & 141.40 \\
\hline & & $\mathrm{NO}_{2}+\mathrm{NO}_{3}$ & 0.88 & 3.06 & 0.87 & 0.42 & 0.78 \\
\hline \multirow{3}{*}{ C-41A Canal } & \multirow{3}{*}{26} & $\mathrm{TP}$ & 9.84 & 60.29 & 5.21 & 4.63 & 27.48 \\
\hline & & TKN & 252.11 & $1,022.67$ & 127.29 & 51.61 & 643.49 \\
\hline & & $\mathrm{NO}_{2}+\mathrm{NO}_{3}$ & 3.12 & 16.36 & 1.11 & 0.69 & 2.06 \\
\hline \multirow{3}{*}{ Total for priority tributaries } & \multirow{3}{*}{$\begin{array}{l}1 \mathrm{~A} \\
\text { to } \\
14\end{array}$} & $\mathrm{TP}$ & 110.61 & 135.95 & 51.61 & 17.86 & 86.47 \\
\hline & & $\mathrm{TKN}$ & 349.66 & 502.81 & 158.87 & 85.23 & 267.02 \\
\hline & & $\mathrm{NO}_{2}+\mathrm{NO}_{3}$ & 9.30 & 27.39 & 14.62 & 3.80 & 7.03 \\
\hline
\end{tabular}

\footnotetext{
${ }^{1}$ Taylor Creek at Grassy Island was established downstream of the Taylor Creek remediation project in August 2004.
} 


\section{Acknowledgments}

Many thanks to Pamela Telis, a USGS liaison with the U.S. Army Corps of Engineers, and also to Donna Schiffer and Sharon Kroening of the USGS, who helped plan and design the Lake Okeechobee Watershed Project. Special gratitude is extended to the editors and peer reviewers for their guidance, assistance, and insight in bringing greater focus to this report.

\section{References Cited}

Burke, P.M., Hill, S., Iricanin, N., Douglas, C., Essex, P., and Tharin, D., 2002, Evaluation of preservation methods for nutrient species collected by automatic samplers: Environmental Monitoring and Assessment, v. 80, no. 2, December 2002, p. 149-173.

Flaig, E.G., and Reddy, K.R., 1995, Fate of phosphorus in the Lake Okeechobee watershed, Florida, USA: Overview and recommendations: Ecological Engineering, no. 5, p. $127-142$.

Glantz, S.A., 2005, Primer of biostatistics: New York, McGraw Hill.

Havens, K.E., James, R.T., East, T.L., and Smith, V.H., 2003, $\mathrm{N}: \mathrm{P}$ ratios, light limitation, and cyanobacterial dominance in a subtropical lake impacted by non-point source nutrient pollution: Environmental Pollution, v. 122, no. 3, p. 379-390.

James, R.T., and Zhang, J., 2008, Chapter 10: Lake Okeechobee Protection Program-State of the lake and watershed: 2008 South Florida Environmental Report, South Florida Water Management District, West Palm Beach, Florida.

McKee, K.A., Clark, M.W., and Grunwald, Sabine, 2008, Soil phosphorus storage in isolated wetlands of improved pastures north of Lake Okeechobee: Greater Everglades Ecosystem Restoration Planning, Policy and Science Meeting, Programs and Abstracts, Naples, Florida, July 28-August 1, 2008, p. 288.
Miller, R.L., and McPherson, B.F., 2008, Water quality in the Arthur R. Marshall Loxahatchee National Wildlife Refuge-Trends and spatial characteristics of selected constituents, 1974-2004: U.S. Geological Survey Scientific Investigations Report 2007-5277, 34 p.

RECOVER, 2003, Draft CERP Quality Assurance System Requirement Manual: Restoration Coordination and Verification Program: Jacksonville, U.S. Army Corps of Engineers; West Palm Beach, South Florida Water Management District.

Schertz, T.L., Alexander, R.B., and Ohe, D.J., 1991, The computer program Estimate Trend (ESTREND), a system for the detection of trends in water-quality data: U.S. Geological Survey Water-Resources Investigations Report 91-4040, 61 p.

State of Florida, 2000, Lake Okeechobee Protection Act: Tallahassee, Fla., Laws of Florida, Chapter 00-130, Section 373.4595 .

U.S. Geological Survey, variously dated, National field manual for the collection of water-quality data: U.S. Geological Survey Techniques of Water-Resources Investigations, book 9, chaps. A1-A9. Also available at http://water.usgs. gov/owq/FieldManual/index.html.

U.S. Geological Survey, 2011, Lake Okeechobee Hydrologic Data: U.S. Geological Survey South Florida Information Access database, accessed January 5, 2011, at http://sofia. usgs.gov/exchange/lowp/.

Zhang J., James R.T., McCormick, P., 2009, Chapter 10: Lake Okeechobee Protection Program-State of the lake and watershed, in 2010 South Florida Environmental Report: West Palm Beach, South Florida Water Management District, v. 1. 


\section{Funding support was provided by the}

U.S. Army Corps of Engineers,

South Florida Water Management District, and

Florida Department of Agriculture and Consumer Services.

For more information concerning this publication contact Michael J. Byrne, Sr.

Hydrologist, Florida Water Science Center - Orlando 12703 Research Parkway

Orlando, Florida 32826

(407) 803-5575 
